\title{
Turonian (Eaglefordian) Stratigraphy of the Atlantic Coastal Plain and Texas
}

U.S. GEOLOGICAL SURVEY PROFESSIONAL PAPER 1315 


\title{
Turonian (Eaglefordian) Stratigraphy of the Atlantic Coastal Plain and Texas
}

\author{
By PAGE C. VALENTINE
}

\section{U.S. GEOLOGICAL SURVEY PROFESSIONAL PAPER 1315}

A discussion of Turonian strata and the Cenomanian-

Turonian boundary beneath the Atlantic and Gulf

Coastal Plains. Revised ages of Upper Cretaceous

stratigraphic units are presented

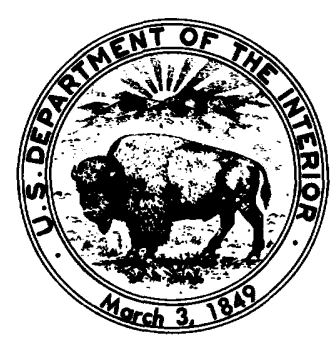

UNITED STATES GOVERNMENT PRINTING OFFICE, WASHINGTON : 1984 


\title{
DEPARTMENT OF THE INTERIOR
}

\author{
WILLIAM P. CLARK, Secretary
}

\section{U.S. GEOLOGICAL SURVEY}

Dallas L. Peck, Director

Library of Congress Cataloging in Publication Data

Valentine, Page C.

Turonian (Eaglefordian) stratigraphy of the Atlantic Coastal Plain and Texas.

(Geological Survey professional paper ; 1315)

Bibliography: $p$.

Supt. of Docs. no. : I 19.16:1315

1. Geology, Stratigraphic—Cretaceous. 2. Geology-Atlantic Coast (U.S.) 3. Geology—Gulf Coast (U.S.)

4. Geologic - Texas - Gulf Region. I. Title. II. Series.

$\begin{array}{llll}\text { QE688.V348 } & 1984 & 551.77^{\prime} 0974 & 83-600335\end{array}$

For sale by the Distribution Branch, U.S. Geological Survey, 604 South Pickett Street, Alexandria, VA 22304 


\section{CONTENTS}

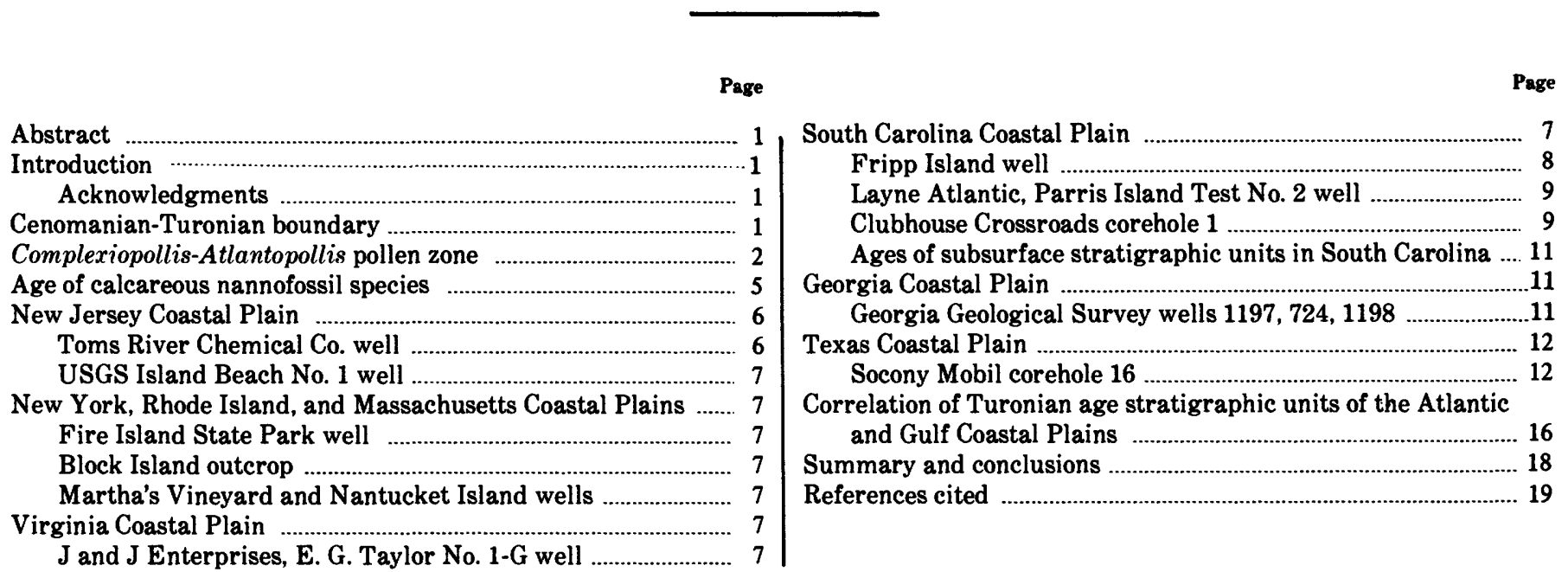

\section{ILLUSTRATIONS}

FIGURE 1. Turonian localities on the Atlantic continental margin

2-9. Diagrams showing:

2. Correlation of upper Cenomanian and lower Turonian stratigraphic units of France, the British Isles, the United States Western Interior, and the Gulf and Atlantic Coastal Plains

3. Upper Cenomanian and Turonian stratigraphy of the Toms River Chemical Co. well, New Jersey

4. Stratigraphic interpretations of the Fripp Island well, South Carolina

5. Stratigraphic interpretations of Clubhouse Crossroads corehole 1, South Carolina

6. Turonian stratigraphy of the Clubhouse Crossroads corehole 1, South Carolina

7. Reinterpreted correlation of Cretaceous stratigraphic units recognized in previous studies of coastal South Carolina with European and Provincial stages

8. Upper Cenomanian, Turonian, and Coniacian stratigraphy of Socony Mobil corehole 16, Dallas, Texas $\quad 13$

9. Correlation of biostratigraphic and lithostratigraphic units of the Atlantic Coastal Plain and Texas ................ 14

10. Generalized correlation chart for upper Cenomanian to lower Campanian strata of the Atlantic and Gulf Coastal Plains

\section{TABLE}





\title{
TURONIAN (EAGLEFORDIAN) STRATIGRAPHY OF THE ATLANTIC COASTAL PLAIN AND TEXAS
}

\author{
By Page C. Valentine
}

ABSTRACT

\begin{abstract}
A stratigraphic analysis of 14 localities from New England to Georgia and of 1 well from the type area of the Eaglefordian Stage at Dallas, Tex., has resulted in a reevaluation of the ages of both formal and informal stratigraphic units previously established for the Atlantic and eastern Gulf Coastal Plains. Lower Turonian strata, once thought to be absent beneath the Atlantic Coastal Plain, are present. The study focused on a stratigraphic interval that is characterized by the presence of distinctive calcareous nannofossil and pollen floras. The Complexiopollis-Atlantopollis pollen assemblage zone, widespread throughout the Atlantic and Gulf Coastal Plains and previously dated as late Cenomanian, is now shown to be late Cenomanian-early Turonian on the Gulf Coast on the basis of its occurrence with calcareous nannofossils, planktic foraminifers, and mollusks of that age. On the Atlantic Coast, only the lower Turonian part of the Complexiopollis-Atlantopollis zone is known to be present. Stratigraphic units that are now assigned to the lower Turonian include (1) the Woodbridge Clay and Sayreville Sand Members of the Raritan Formation, New Jersey; (2) the upper part of the Rari$\tan$ equivalent beneath the eastern shore of Virginia; (3) the Tuscaloosa equivalent (informal units K2, E, and part of F) in the South Carolina and Georgia coastal region; (4) the Tuscaloosa Formation of eastern Alabama and western Georgia; and, beneath the Gulf Coastal Plain (5) the Coker Formation of western Alabama and (6) the upper Britton and lowermost Arcadia Park Formations at Dallas, Tex. Cenomanian strata beneath the Atlantic Coastal Plain are now interpreted to be much thinner than previously supposed. The lower Turonian there is bounded by upper Turonian and uppermost Cenomanian hiatuses of regional extent, whereas the upper Cenomanian-Turonian section is relatively complete at Dallas, Tex.
\end{abstract}

\section{INTRODUCTION}

Recent interpretations of the Upper Cretaceous stratigraphy of the Atlantic Coastal Plain have shown a relatively thick section of Cenomanian strata bounded above by a hiatus that encompasses at least early Turonian time in the Raritan Embayment of New Jersey and all of Turonian and Coniacian time in the Southeast Georgia Embayment of South Carolina and Georgia (Gohn and others, 1978, 1980; Christopher, 1979a, 1982). These conclusions have been based in part on the correlation of molluscan faunas of the Atlantic Coastal Plain with Cenomanian faunas of the Texas Gulf Coast (Stephenson, 1952, 1954) and partly on spores and pollen that have been compared with floras in Texas strata that have been dated as Cenomanian by using planktic foraminifers and mollusks (Christopher, 1982).

In South Carolina and Georgia, the Cenomanian is reported to be 300 to $600 \mathrm{ft}$ thick beneath the coast, and Turonian and. Coniacian strata are thought to be absent there (Gohn and others, 1978, 1980). In contrast, biostratigraphic studies of the COST No. GE-1 well offshore in the southeast Georgia Embayment (fig. 1, locality 14) have shown that Turonian and Coniacian limestone at least $600 \mathrm{ft}$ thick overlies a thin, $150-\mathrm{ft}$ interval of undated shallow-water, calcareous sandstone of possible Cenomanian age (Valentine, 1979a,b). This finding, and my observation of calcareous nannofossil assemblages of probable Turonian age in beds beneath the Atlantic and Gulf Coastal Plains that have been dated as Cenomanian in the reports cited above, has prompted a reevaluation of the age of this controversial stratigraphic interval. The present study is based on information from 13 wells and 1 outcrop on the Atlantic continental margin (fig. 1) and on 1 well from the Gulf Coastal Plain at Dallas, Tex. (table 1). The depths of samples and stratigraphic boundaries mentioned in the following discussion are given in feet as originally designated during drilling.

The purpose of this report is (1) to delineate Turonian strata and the Cenomanian-Turonian boundary beneath the Atlantic Coastal Plain in New England, New York, New Jersey, Virginia, South Carolina, and Georgia and beneath the Gulf Coastal Plain at Dallas, Tex., by using calcareous nannofossils and by dating a distinctive pollen zone that is present throughout the region and (2) to revise the ages of some Upper Cretaceous stratigraphic units that had been established previously for Atlantic and Gulf Coastal Plain deposits.

\section{ACKNOWLEDGMENTS}

I wish to thank W. V. Sliter and J. E. Hazel of the U.S. Geological Survey, Stefan Gartner of Texas A\&M University, and J. D. Powell of Grand Junction, Colo., for critically reviewing the manuscript. I am particularly grateful to Joe Hazel and Dan Powell for the interest and insight they brought to our discussions of the problem.

\section{CENOMANIAN-TURONIAN BOUNDARY}

Until type sections are chosen for the Cenomanian and Turonian Stages, some controversy will exist regarding the identification and placement of the Cenomanian-Turonian boundary in the European and North American rock record. I have reviewed this problem (fig. 2; Valentine, 1982) and found that the workers who base their interpretation on the evolution 


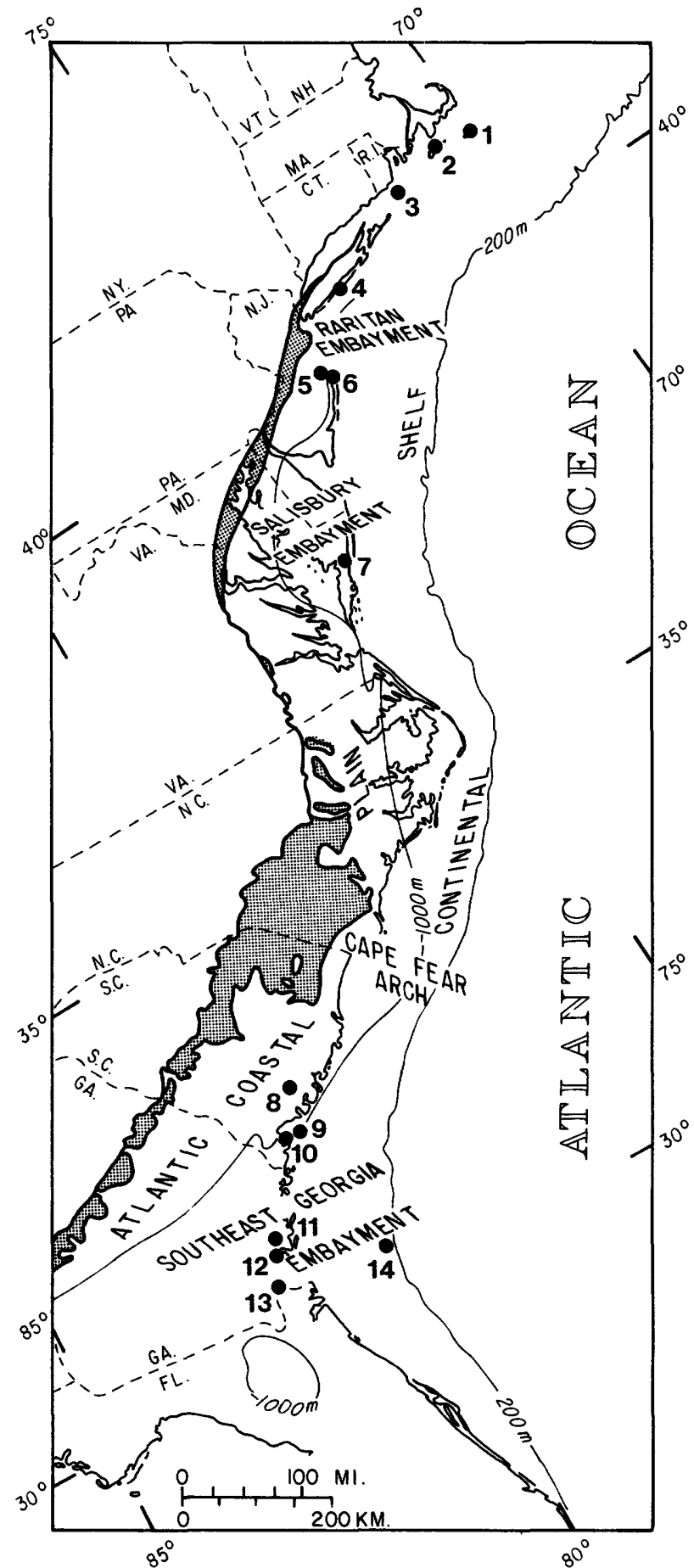

Figure 1.-Turonian localities (numbered 1-14) on the Atlantic continental margin referred to in this study (see table 1). Line labeled $1,000 \mathrm{~m}$ is depth to basement. Shaded area is Cretaceous outcrop.

of mollusks place the boundary either within an interval equivalent to the Sciponoceras gracile zone or at its lower or upper boundary (Basse, 1959; Hancock, 1959; Lecointre, 1959; Cobban and Scott, 1972; Kennedy and Juignet, 1973; Kennedy and Hancock, 1976; Juignet,
1976; Juignet and others, 1978; Rawson and others, 1978).

Studies of coeval sections in Europe and North America have shown that the planktic foraminifer genus Rotalipora became extinct within the Sciponoceras gracile zone or its equivalent (Magne and Polveche, 1961; Jefferies, 1962; Porthault and others, 1967; Robaszynski, 1971, 1976; Eicher and Worstell, 1970; Smith, 1975; Robaszynski and Caron, 1979), and I follow those stratigraphers who have adopted the Rotalipora extinction event as a reliable datum for the practical determination of the Cenomanian-Turonian boundary (van Hinte, 1976). The recognition of Turonian strata beneath the Atlantic and Gulf Coastal Plains depends primarily on the age of a pollen assemblage zone and on the age of several distinctive calcareous nannofossil species.

\section{COMPLEXIOPOLLIS-ATLANTOPOLLIS POLLEN ZONE}

The Complexiopollis-Atlantopollis assemblage zone (Christopher, 1979a) is a distinctive and widespread biostratigraphic unit that is used to identify Cenomanian strata beneath the Atlantic and Gulf Coastal Plains. This pollen zone is based on a previously described unit, pollen zone IV, that is present in outcropping and subsurface strata of the middle and north Atlantic Coastal Plain (Doyle, 1969a; Doyle and Robbins, 1977). In outcrop, the Woodbridge Clay Member and the underlying Farrington Sand Member of the Raritan Formation in New Jersey were placed in pollen zone IV, as were correlative strata in wells in New Jersey and Virginia. Among the characteristics of zone IV is the occurrence of only two genera of the triporate Normapolles group of angiosperms, Complexiopollis and Atlantopollis. These two genera occur together in the Woodbridge Clay Member, whereas lower in the zone only Complexiopollis is present.

The age of pollen zone IV strata was considered to be middle and (or) late Cenomanian by some workers (Doyle, 1969a; Wolfe and Pakiser, 1971; Christopher, 1979a) on the basis of European palynomorph biostratigraphy and on a molluscan fauna from the Woodbridge Clay Member (Richards, 1943; Stephenson, $1952,1954)$. However, Doyle $(1969 \mathrm{~b})$ and Doyle and Robbins (1977) pointed out that Complexiopollis and Atlantopollis are important elements in the Turonian of Europe, and they speculated that the upper part of zone IV could be early Turonian in age.

Christopher (1979a) renamed pollen zone IV and redefined it to include only the Woodbridge Clay Member and the overlying Sayreville Sand Member of the Raritan Formation, thereby excluding the Far- 
TABLE 1.-Turonian localities on the Atlantic and Gulf Coastal Plains

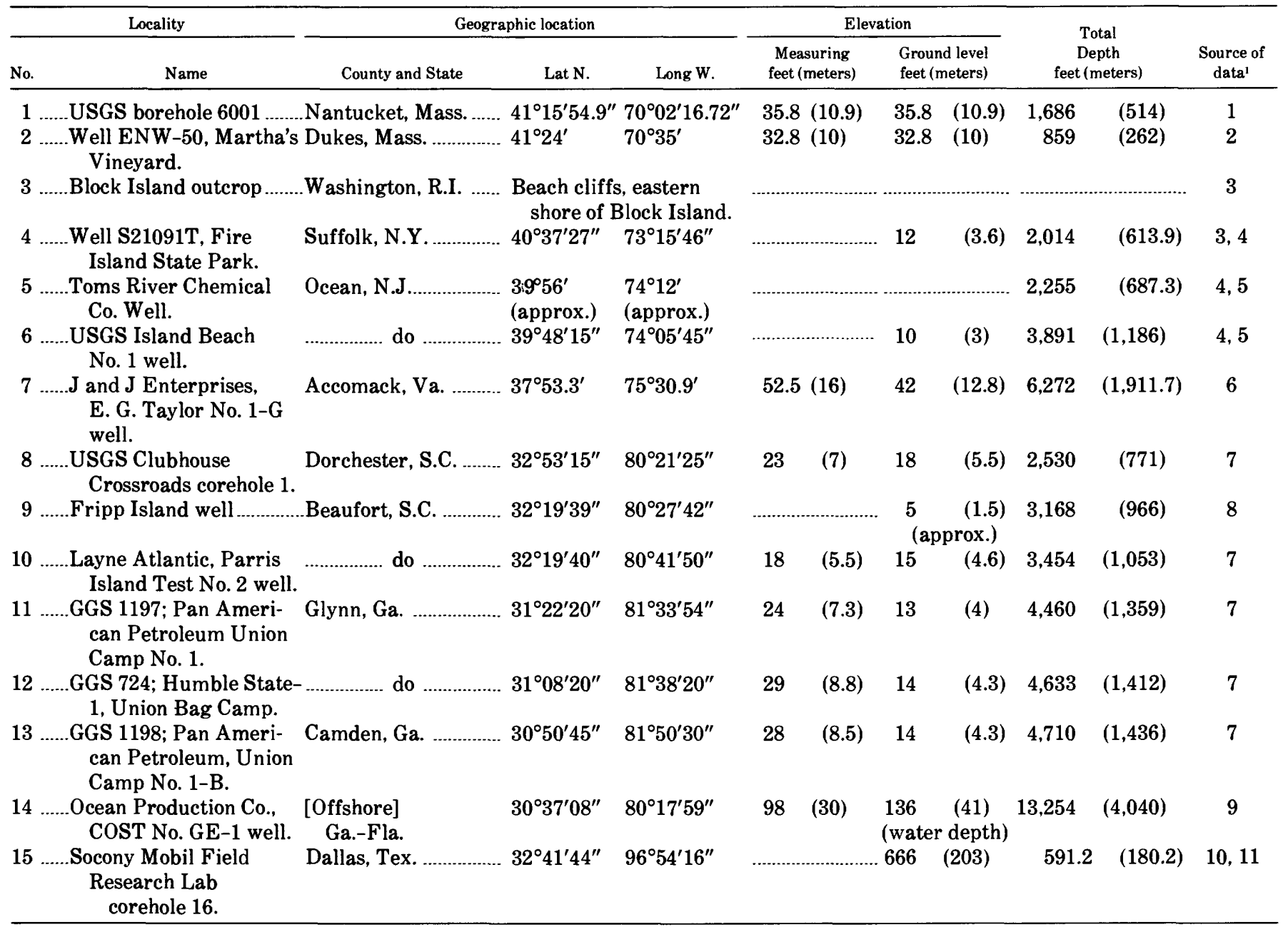

'Sources of data: (1) Folger and others, 1978; (2) Hall and others, 1980; (3) Sirkin. 1974; (4) Brown and others, 1972; (5) Petters, 1976: (6) Robbins and others, 1975; (7) Brown and others 1979; (8) Gohn and others, 1978; (9) Scholle, 1979; (10) Brown and Pierce, 1962; (11) Christopher, 1982.

rington Sand Member. A necessary criterion of Christopher's new Complexiopollis-Atlantopollis assemblage zone is the occurrence of the nominate genera and the absence of other Normapolles genera, and therefore the new zone does not include the lower part of pollen zone IV where only Complexiopollis is present. The stratotype of the new zone is the Woodbridge Clay Member exposed in the Raritan Bay region of northern New Jersey (Christopher, 1979a, p. 100, fig. 4). The Complexiopollis-Atlantopollis assemblage zone was dated as middle to late Cenomanian on the basis of the first occurrence of Complexiopollis in middle Cenomanian strata of Europe and of the Atlantic and Gulf Coastal Plains (Christopher, 1979a, and references therein). This conclusion has influenced the most recent stratigraphic interpretations of the South Carolina and Georgia Coastal Plain (Gohn and others, 1978, 1980).
The Woodbridge Clay Member of northern New Jersey, the stratotype of the Complexiopollis-Atlantopollis zone, was dated as Cenomanian on the basis of its dominantly molluscan macrofauna, which is poorly preserved, chiefly as molds and casts (Richards, 1943; Stephenson, 1954). The age of the Woodbridge fauna was addressed by Stephenson in 1952; after he studied a new fossil collection in 1954, he concluded that "the Raritan Formation, particularly in the lower part [Woodbridge Clay Member], corresponds approximately in age to the Woodbine Formation (Cenomanian) of Texas ***" (Stephenson, 1954, p. 25). The Cenomanian age of the Woodbine Formation is not in dispute as it is based on the presence of ammonite and bivalve species that are close relations or analogs of species found in the Cenomanian strata of France and England (Stephenson, 1952, p. 24). On the other hand, a comparison of the Woodbridge Clay Member fauna 


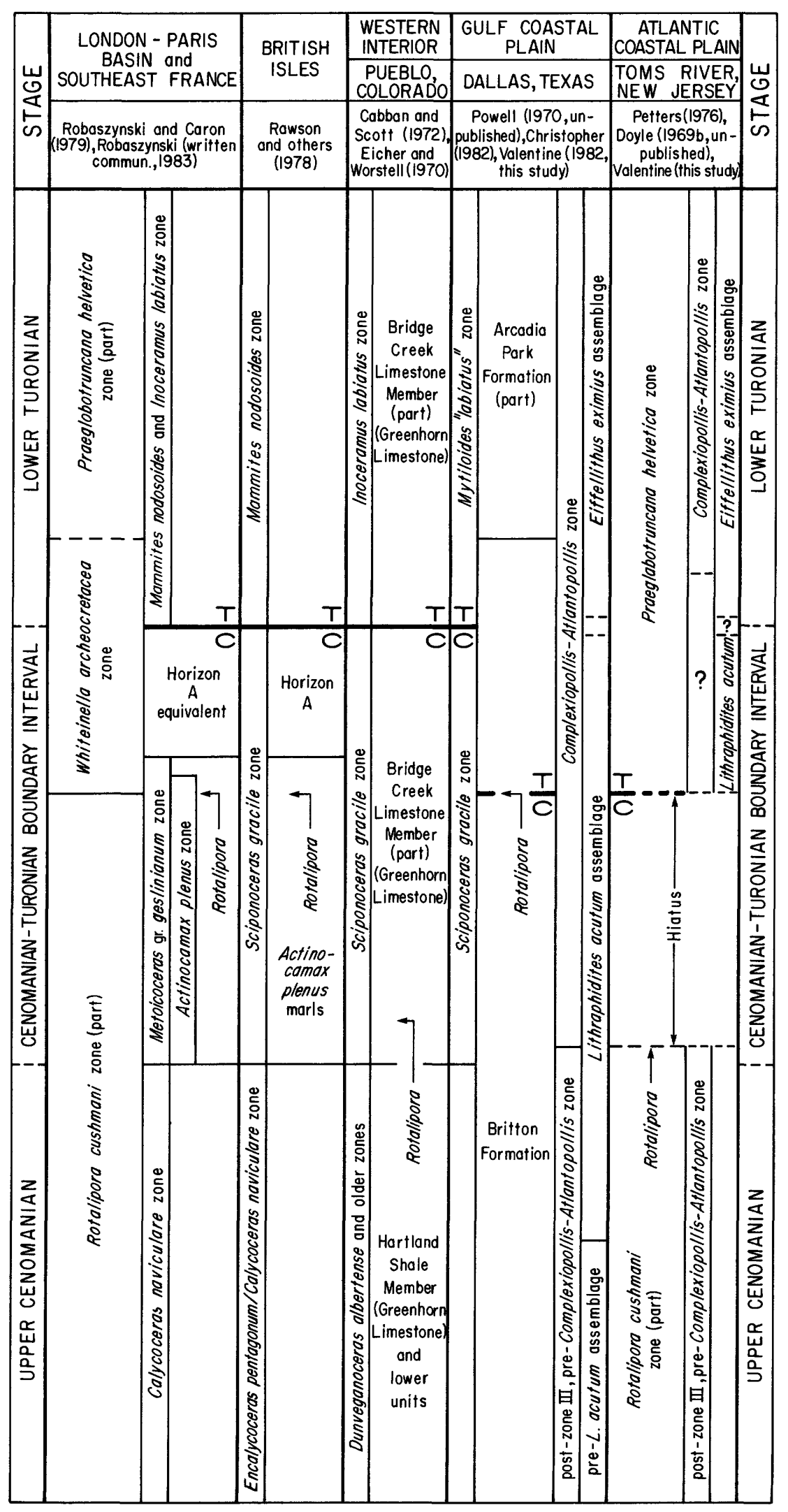

FIGURE 2.-Correlation of upper Cenomanian and lower Turonian stratigraphic units of France, the British Isles, the United States Western Interior, and localities on the Gulf and Atlantic Coastal Plains. The Sciponoceras gracile assemblage zone and the highest occurrence of Rotalipora, shown by horizontal arrows, are in the Cenomanian-Turonian boundary interval. Heavy horizontal line indicates the Cenomanian-Turonian boundary of various authors; T (Turonian), C (Cenomanian). No vertical scale. At Dallas, Tex., J. D. Powell of Grand Junction, Colo., studied outcrops; R. A. Christopher and Valentine studied the same core. 
with that of the Eagle Ford Group (CenomanianTuronian) of Texas was not possible because the molluscan fauna of the Eagle Ford, which overlies the Woodbine Formation, had not been adequately studied and described (Stephenson, 1952, p. 25). Only two molluscan species from the Woodbridge Clay Member are definitely identified as occurring in the Woodbine Formation, while the rest are either related only to Woodbine forms or their identification is questioned by Stephenson. More significantly, a recent study by Christopher (1982) has shown that the molluscan correlation of the Woodbridge Clay Member and the Woodbine Formation is not valid because the Complexiopollis-Atlantopollis pollen assemblage of the Woodbridge Clay Member is not present either in the Woodbine Formation of Texas or in the Tarrant Formation, the basal formation of the overlying Eagle Ford Group. However, the pollen assemblage is present higher in the Eagle Ford in the middle and upper part of the Britton Formation and in the lower part of the Arcadia Park Formation, and it is now interpreted by Christopher (1982, oral commun., 1981), to be late Cenomanian and possibly, in the uppermost part, early Turonian in age.

The present study is based on the stratigraphy of wells on the Atlantic and Gulf Coastal Plains, and the results suggest that the Complexiopollis-Atlantopollis zone is early Turonian in age beneath the Atlantic Coastal Plain but that it ranges from late Cenomanian to early Turonian beneath the Gulf Coastal Plain at Dallas, Tex. (fig. 2).

The distinctive Complexiopoll is-Atlantopollis zone assemblage has been reported from many localities on the Atlantic margin including Martha's Vineyard and Nantucket Island, Mass. (Folger and others, 1978; Christopher, 1979a; Hall and others, 1980); Block Island, R.I. (Sirkin, 1974); Long Island, N.Y. (Sirkin, 1974; Perry and others, 1975); New Jersey (Doyle, 1969a,b; Perry and others, 1975); Virginia (Robbins and others, 1975; Doyle and Robbins, 1977); North Carolina (Christopher and others, 1979); South Carolina (Gohn and others, 1978); and Georgia (Gohn and others, 1980). The assemblage also is present in the Tuscaloosa Group of Georgia and Alabama (Leopold and Pakiser, 1964; Phillips and Felix, 1971; Christopher, 1979a,b) and in the Eagle Ford Group of Texas (Christopher, 1982). Offshore, it has been reported from the COST No. GE-1 well off Georgia.

\section{AGE OF CALCAREOUS NANNOFOSSIL SPECIES}

Establishing the ages of several key nannofossil species that are present in the stratigraphic interval under study here is important. In a worldwide study of Jurassic and Cretaceous strata, Thierstein (1976, fig. 7 and pl. 3, figs. 39, 40) concluded that Corollithion achylosum ranges from the Aptian to the latest Turonian. This species is restricted to rocks independently dated with planktic foraminifers as Turonian and older in the COST No. B-2, B-3, and GE-1 wells drilled on the Atlantic margin (Valentine, 1977, 1979b, 1980; Poag, 1977, 1980; Poag and Hall, 1979); a reevaluation of the COST No. B-2 well (Valentine, 1980) revealed a previous reference to C. achylosum (Valentine, 1977, p. 39) to be incorrect. On the Texas Coastal Plain, $C$. achylosum has not been reported from strata younger than Turonian (Gartner, 1968; Bukry, 1969; Smith, 1981). I found that in a core from the Eagle Ford and Austin Groups at Dallas, Tex. (Socony Mobil corehole 16; Brown and Pierce, 1962; Pessagno, 1969), the highest occurrence of $C$. achylosum is in the upper part of the Arcadia Park Formation (upper Turonian); $C$. achylosum does not range into the overlying Atco Formation (Coniacian). In contrast, Verbeek (1977a) reported that $C$. achylosum ranged as high as the Campanian, but this range appears to be based on an early paper by Thierstein (1973) and not on that author's later report (Thierstein, 1976). Moreover, Verbeek's (1976, 1977a) studies in Tunisia and Spain showed that $C$. achylosum is restricted to Turonian and older strata except for a single occurrence in "Coniacian" beds that are probably Turonian in age (Valentine, 1982).

Eiffellithus eximius was reported by Thierstein (1976, fig. 7 and pl. 5, figs. 28, 29) to range from the middle Turonian to the Campanian-Maestrichtian boundary, and Stover (1966) reported it as ranging throughout the Turonian. Wonders and Verbeek (1977) have shown that the first occurrence of E. eximius in the El Kef section of Tunisia is in the Turonian, above the extinction level of Rotalipora, and the same relation exists in a section at Javernant, France(Verbeek, 1977b; de Vries, 1977). Manivit and others (1977) indicated the initial appearance of E. eximius was in the upper Turonian, but subsequently, Manivit and others (1979) showed it first appeared in the middle Turonian. Eiffellithus eximius occurs with Corollithion achylosum in the Fripp Island and Clubhouse Crossroads wells of South Carolina and in strata dated as Turonian in previous studies in the Dallas, Tex., core (Christopher, 1982; Powell, written and oral commun., 1981, 1982), in the Island Beach and Toms River wells of New Jersey (Petters, 1976), and in the COST No. B-2, B-3, and GE-1 wells offshore (Valentine, 1979b, 1980,1982 ).

A third stratigraphically important calcareous nannofossil species is Lithraphidites acutum. This species has been reported as ranging from middle Cenomanian to middle Turonian, although its last occurrence in the Turonian is not well documented 
(Manivit and others, 1977, pl. 1, figs. 1, 7, 8). In the present study, L. acutum disappeared before the first appearance of Eiffellithus eximius, as reported by Manivit and others (1977). Lithraphidites acutum is present in the Fripp Island and Clubhouse Crossroads wells in South Carolina, in the Dallas corehole in Texas, and in strata dated as early Turonian with foraminifers (Petters, 1976) in the Toms River and Island Beach wells in New Jersey.

Two distinct nannofossil assemblages have been identified in this study. They are present in, but are not confined to, the Complexiopollis-Atlantopollis pollen zone, which is an important biostratigraphic unit that is found in the subsurface and in outcrops of the Coastal Plain from New England to Texas. The Lithraphidites acutum assemblage is present in the lower part of the Complexiopollis-Atlantopollis zone and contains Lithraphidites acutum, Corollithion achylosum, Cretarhabdus lorei. Cruciellipsis chiastia, Parhabdolithus asper, and Podorhabdus albianus. The somewhat younger Eiffellithus eximius assemblage is found in the upper part of the ComplexiopollisAtlantopollis zone and contains Eiffellithus eximius, Corollithion achylosum, and possibly Cretarhabdus lorei.

\section{NEW JERSEY COASTAL PLAIN}

\section{TOMS RIVER CHEMICAL CO. WELL}

The Raritan Formation exposed in northern New Jersey does not contain calcareous microfossils, but, 38 mi south of Raritan Bay, the formation, including the Woodbridge Clay Member, has been delineated in the Toms River Chemical Co. well through lithological, geophysical, and, most importantly, palynological correlations based on core samples (Perry and others, 1975). Pollen zone IV was recognized from about 1,300 to $1,500 \mathrm{ft}$, and the Woodbridge from about 1,300 to $1,430 \mathrm{ft}$ (Perry and others, 1975, fig. 11). J. A. Doyle, who analyzed the spores and pollen in this well for the study by Perry and others, reported beds equivalent to the Woodbridge Clay Member and containing only Complexiopollis and Atlantopollis of the Normapolles group to be present at 1,298 to $1,300 \mathrm{ft}$ and 1,369 to $1,371 \mathrm{ft}$ and only Complexiopollis to be present at 1,437 to $1,439,1,460$, and $1,528 \mathrm{ft}$ (Doyle, $1969 \mathrm{~b}$, oral commun., 1981). The interval from 1,298 to at least $1,371 \mathrm{ft}$ in the Toms River well (figs. 2 and 3 ) correlates with the Complexiopollis-Atlantopollis zone of Christopher (1979a). The age of the Complexiopollis-Atlantopollis zone can be determined because both planktic foraminifers and calcareous nannofossils occur in this interval of the Toms River well. The extinction of Rotalipora is accepted here as marking the Ceno-

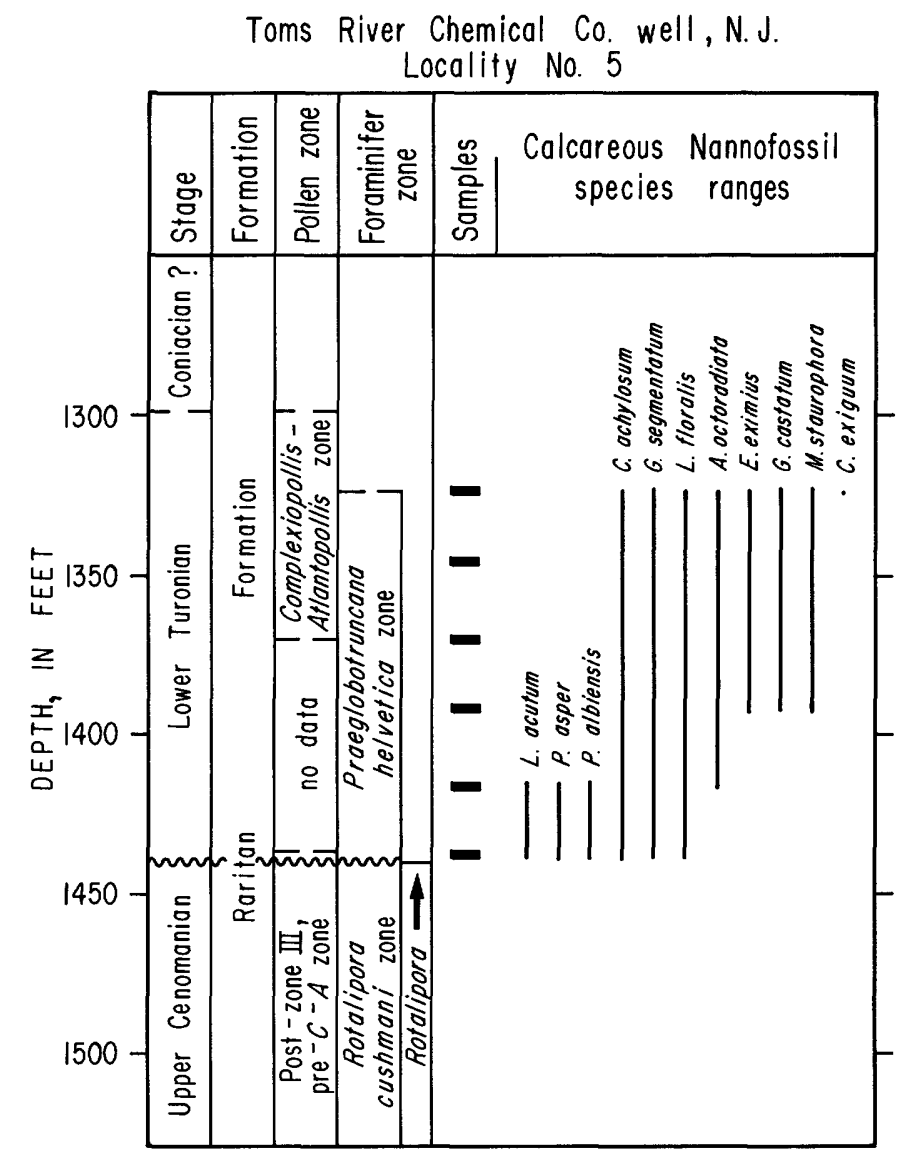

Figure 3.-Upper Cenomanian and Turonian stratigraphy, calcareous nannofossil ranges, and the occurrence of the Complexiopollis-Atlantopoll is zone in the Toms River Chemical Co. well, New Jersey. Pollen stratigraphy adapted from the work of Doyle (1969b, oral commun., 1981). Planktic foraminifer stratigraphy from Petters (1976). Blacked-in areas represent cores studied for nannofossils. A hiatus (wavy line) is interpreted to exist between the upper Cenomanian and lower Turonian. Depth scale is original depth.

manian-Turonian boundary, and Petters (1976, fig. 6) showed this datum to be at $1,440 \mathrm{ft}$ at Toms River, below the Complexiopollis-Atlantopollis interval; he also recognized the lower Turonian Praeglobotruncana helvetica zone in the interval from 1,323 to 1,440 $\mathrm{ft}(1976$, p. 96, fig. 6). I have identified calcareous nannofossil assemblages that corroborate the early Turonian age determination for the Woodbridge Clay Member (Complexiopollis-Atlantopollis zone) in the well. An analysis of four core samples $(1,323-1,325$, $1,345-1,347,1,369-1,371$, and 1,391-1,393 ft) revealed the age of this interval to be Turonian on the basis of the occurrence of Corollithion achylosum and Eiffellithus eximius. Lower in the section (1,415-1,417 and 1,437-1,439 ft), the highest occurrence of Lithraphidites acutum and Podorhabdus albianus at 1,415 ft and the presence of Corollithion achylosum and Podorhabdus albianus at $1,437 \mathrm{ft}$ suggest an early Turonian age 
for these beds that lie above the Rotalipora extinction at $1,440 \mathrm{ft}$.

\section{USGS ISLAND BEACH NO. 1 WELL}

The USGS Island Beach No. 1 well is located about 10 mi southeast of the Toms River well, and the Cenomanian-Turonian biostratigraphy of the two wells is similar. Petters (1976, p. 93, fig. 6) delineated the lower Turonian Praeglobotruncana helvetica zone from 1,950 to $2,200 \mathrm{ft}$, the highest occurrence of Rotalipora. In the same interval, a Complexiopollis-Atlantopollis zone flora is present in sidewall cores from 2,004 and 2,200 ft (Christopher, oral commun., 1979), and I have identified calcareous nannofossils that I interpret to be Turonian in age from the same cores. The core from $2,004 \mathrm{ft}$ contains Corollithion achylosum, Eiffellithus eximius, and other species. The nannofossil assemblage from $2,200 \mathrm{ft}$ is similar, except that $E$. eximius is absent and Lithraphidites acutum is present.

\section{NEW YORK, RHODE ISLAND, AND MASSACHUSETTS COASTAL PLAINS}

\section{FIRE ISLAND STATE PARK WELL}

The Atlantic Coastal Plain narrows in northern New Jersey as the continental margin turns eastward to New England. Cretaceous strata are confined to the subsurface in the coastal region from New York to Massachusetts except where they have been transported southward and exposed by the advance of Pleistocene glaciers. The Complexiopollis-Atlantopollis zone assemblage is present in cores collected between 1,800 and $1,873 \mathrm{ft}$ in a deep well drilled in Fire Island State Park (S21091T) off the south coast of Long Island, N.Y. (Sirkin, 1974). This interval has been correlated with the Woodbridge Clay Member of the Raritan Formation and pollen zone IV by Perry and others (1975, fig. 11). The Complexiopollis-Atlantopollis zone flora is from a part of the Fire Island well that was assigned to unit $\mathrm{F}$ by Brown and others (1972).

\section{BLOCK ISLAND OUTCROP}

Block Island off the coast of Rhode Island is the site of an exposure of Upper Cretaceous strata that were transported and tilted during a Pleistocene glacial advance. Sirkin (1974) reported the occurrence of Complexiopollis and Atlantopollis in lignite seams from beach cliffs there that indicates a correlation with the Complexiopollis-Atlantopollis zone of the Woodbridge Clay Member.

\section{MARTHA'S VINEYARD AND NANTUCKET ISLAND WELLS}

Two wells drilled on Martha's Vineyard and Nantucket Island, Mass., encountered beds that can be assigned to the Complexiopollis-Atlantopollis zone. In the ENW-50 well on Martha's Vineyard, R. A. Christopher identified the Woodbridge flora in three splitspoon samples from 550, 600, and $835.5 \mathrm{ft}$ (Hall and others, 1980). On Nantucket Island, Christopher found the same flora in cores from 850.4, 940.0, 1076.1, 1083.0 , and $1104.3 \mathrm{ft}$ in the USGS borehole 6001 (Folger and others, 1978; Valentine, 1981).

\section{VIRGINIA COASTAL PLAIN}

\section{J. AND J. ENTERPRISES, E. G. TAYLOR NO. 1-G WELL}

The Complexiopollis-Atlantopollis zone flora is present also in the E. G. Taylor No. 1-G well on the eastern shore of Virginia, the only reported occurrence of the flora from the Coastal Plain between New Jersey and North Carolina. The stratigraphy of the well has been studied by Robbins and others (1975) and Doyle and Robbins (1977) who studied the palynomorphs and also incorporated into their interpretation information provided by M. Ruth Todd about foraminifers from a 195 -ft interval $(1,325-1,520 \mathrm{ft})$.

Robbins and others (1975) examined cores and sidewall cores and delineated pollen zone IV from 1,450 to $1,560 \mathrm{ft}$. The pollen distribution presented in their report indicates that the ComplexiopollisAtlantopollis zone, as defined by Christopher (1979a), is present in a short interval from 1,450 to $1,480 \mathrm{ft}$; foraminifer species in the same interval are not age diagnostic and could be Turonian or Cenomanian, but Rotalipora greenhornensis is present lower in the section at $1,520 \mathrm{ft}$. Although Rotalipora occurs in a single sample, the pattern of stratigraphic succession, Rotalipora followed by Complexiopollis-Atlantopollis zone strata of early Turonian age, is similar to that observed in the Toms River, N.J., well.

\section{SOUTH CAROLINA COASTAL PLAIN}

Brown and others (1979) and Gohn and others $(1978,1980)$ have delineated the Upper Cretaceous stratigraphy beneath the South Carolina Coastal Plain on the basis of lithologic and electric log correlations that are supplemented by paleontological interpretations. These authors studied many of the same wells, but their stratigraphic units often do not coincide. They also do not agree on the age of the lower part of the Upper Cretaceous section or on the placement of hiatuses. The results of the study of a deep stratigraphic test well (COST No. GE-1) on the Outer Continental Shelf off Georgia (Valentine, 1979a,b) prompted a reevaluation of the ages of Cretaceous strata that underlie the Georgia and South Carolina Coastal Plains. The three South Carolina wells treated here have been studied by other workers, and they are part 
of a broader investigation (Valentine, 1982) to revise the Upper Cretaceous stratigraphic framework previously established for the South Carolina-Georgia coastal region.

\section{FRIPP ISLAND WELL}

The Upper Cretaceous biostratigraphy of the Fripp Island well (fig. 4) has been studied in more detail than that of other wells in coastal South Carolina; the study involved the examination of 279 cuttings samples at 94 levels in the approximately 1,700$\mathrm{ft}$ Upper Cretaceous interval. There is a $263-\mathrm{ft}$ sampling gap in the Campanian part of the section. Cuttings were collected over 10 -ft intervals, and individual rock chips representative of each lithologic unit in a sample were examined. Calcareous nannofossils are, for the most part, abundant and well preserved, and the stratigraphy of the well is based on the ranges of the following selected species: Micula mura $(1,507$ $\mathrm{ft})$; Tetralithus aculeus (1,507-1,907 ft); T. trifidus (1,527-1,970 ft); Broinsonia parea (1,527-2,427 ft); Eiffellithus eximius $(1,808-3,147 \mathrm{ft}$, lowest sample); Lithastrinus grillii (2,263-2,867 ft); Chiastozygus cuneatus $(2,427-3,007 \mathrm{ft}) ;$ Lithastrinus floralis $(2,457-3,147$ $\mathrm{ft}$, lowest sample); Marthasterites fureatus (2,457-2,857 $\mathrm{ft})$; and Corollithion achylosum $(3,057-3,147 \mathrm{ft}$, lowest sample).

The Cretaceous-Tertiary boundary is at $1,437 \mathrm{ft}$, and the Maestrichtian-Campanian boundary is at $1,808 \mathrm{ft}$. The top of the Santonian is at $2,427 \mathrm{ft}$, and both Santonian and Coniacian cuttings are present down to at least $2,637 \mathrm{ft}$, where an unfossiliferous quartz sand appears that extends down to $3,057 \mathrm{ft}$. The 420 -ft thick sand may be Coniacian in age, but, because I could not determine the boundary between the Santonian and Coniacian Stages, the entire interval from 2,427 to $3,057 \mathrm{ft}$ is treated as Santonian-Coniacian. Below the quartz sand, there is a marked change in lithology to gray, calcareous sandy or silty shale and gray limestone (Gohn and others, 1978). Three samples (3,057-3,067, 3,097-3,107, and 3,137-3,147 ft) from this unit contain a Turonian Eiffellithus eximius assemblage that includes, among other species, $A h m u$ ellerella octoradiata, Corollithion achylosum, C. exiguum, Eiffellithus eximius, and Lithastrinus floralis; two samples $(3,097-3,107$ and $3,127-3,137 \mathrm{ft})$ within this interval contain a Complexiopollis-Atlantopollis zone flora (R. A. Christopher, unpub. data, 1977). Planktic foraminifers dated as Turonian or Coniacian, but not older than Turonian, are present in a sample from 3,117 to 3,127 ft (C. C. Smith, un pub. data, 1977). Samples are not available from the lowest $21 \mathrm{ft}$ of the section, and the well did not penetrate crystalline basement rocks (Gohn and others, 1978).

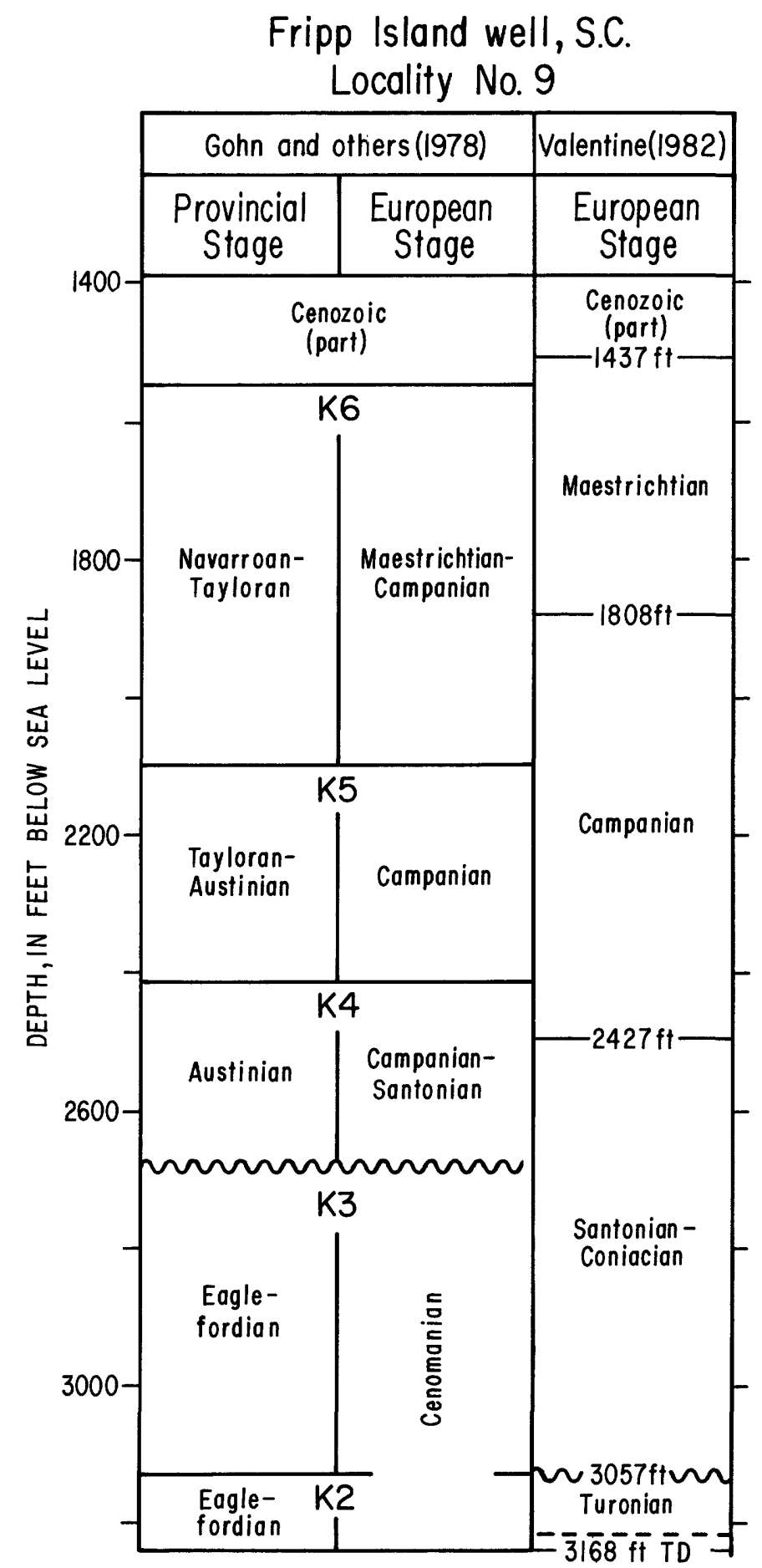

FIGURE 4.-Stratigraphic interpretations of the Fripp Island well, South Carolina. K2-K6 are unnamed stratigraphic units of Gohn and others (1978). Depth scale is relative to sea level; stratigraphic boundaries are given in original depths (for depth below sea level; subtract $5 \mathrm{ft}$ ). Wavy lines represent unconformities.

My interpretation of the upper part of the Fripp Island section agrees with that of Gohn and others (1978). However, in the lower part of the well, those authors interpreted their units $\mathrm{K} 2$ and $\mathrm{K} 3$ to be Cenomanian in age, and they recognized a major hiatus 
between units $\mathrm{K} 3$ and $\mathrm{K} 4$ that represents Coniacian and Turonian time. In contrast, I believe that unit K3 is Santonian-Coniacian in age and that unit K2 is early Turonian.

\section{LAYNE ATLANTIC, PARRIS ISLAND TEST NO. 2 WELL}

The Upper Cretaceous stratigraphic units of Brown and others (1979) and Gohn and others (1978, 1980) can be compared in the Parris Island Test No. 2 well; further, correlation is possible with the Fripp Island well, only $11 \mathrm{mi}$ to the west, where the units of Gohn and others can be dated with nannofossils and pollen. Gohn and others $(1978,1980)$ based their correlation of the two wells on electric logs and paleontological analyses. Brown and others (1979) presumably used lithologic characteristics and the occurrence of key species of ostracodes and foraminifers to interpret the Parris Island well. The lowest units outlined in the well by these studies are physically the same, but Brown and others (1979) assigned them to unit $\mathrm{E}$ (Woodbinian) and Unit F (Washitan and Fredericksburgian), whereas Gohn and others $(1978,1980)$ considered them to be younger and placed them, respectively, in unit K2 (middle Eaglefordian) and unit K1 (Upper(?) Cretaceous).

I have reinterpreted, in part, the electric logs published by Gohn and others (1978, sheet 2) to correlate strata in the Parris Island well with units I have dated at FrippIsland (Valentine, 1982). The beds in the lower part of the Parris Island well appear to be younger than the previous authors have indicated, and I interpret unit E (Cenomanian) of Brown and others (1979) and unit K2 (Cenomanian) of Gohn and others (1978, 1980 ) to be early Turonian in age. The age of the lowest unit in the Parris Island well is unknown at present.

\section{CLUBHOUSE CROSSROADS COREHOLE 1}

The Clubhouse Crossroads corehole 1 (fig. 5) is 42 mi north of the Parris Island and Fripp Island wells. The lithology and paleontology of the core have been studied by Gohn and others (1977) and Hazel and others (1977), and this corehole has been incorporated into the stratigraphic frameworks of Gohn and others (1978) and Brown and others (1979). Their age interpretations are coincident down to the base of the Austinian Stage. At that level, Gohn and others (1978) indicated the presence of a major disconformity between units K4 and K3; Gohn and others (1980) assigned units $\mathrm{K} 3$ and $\mathrm{K} 2$ below the hiatus to the middle Eaglefordian and assigned unit K1 to the Upper(?) Cretaceous. Brown and others (1979) interpreted the same interval to include strata of unit D (Eaglefordian) separated by a hiatus representing unit $\mathrm{E}$ (Wood- binian) from the underlying rocks of unit $F$ (Washitan and Fredericksburgian).

Hazel and others (1977), by using planktic foraminifers, have shown that the Tertiary-Maestrichtian boundary is at approximately $804 \mathrm{ft}$, that the Maestrichtian-Campanian contact is at about $1,030 \mathrm{ft}$, and that Campanian strata extend down to approximately $1,706 \mathrm{ft}$. The interval from 1,706 to $2,342 \mathrm{ft}$ is poorly fossiliferous, but spore and pollen flora typical of the Magothy Formation and the underlying South Amboy Fire Clay Member of the Raritan Formation of New Jersey are present down to 1,906 ft (Hazel and others, 1977). The Magothy and the South Amboy assemblages belong to the tripartite pollen zone $\mathrm{V}$ of Christopher $(1977,1979 a$, and 1982) that is chiefly Santonian in age but that also includes strata of early Campanian and late Coniacian age (R. A. Christopher, oral commun., 1979). I have examined a sample from $1,752 \mathrm{ft}$ that contains a rich Santonian nannofossil assemblage; a sample from $1,943 \mathrm{ft}$, however, contains only rare

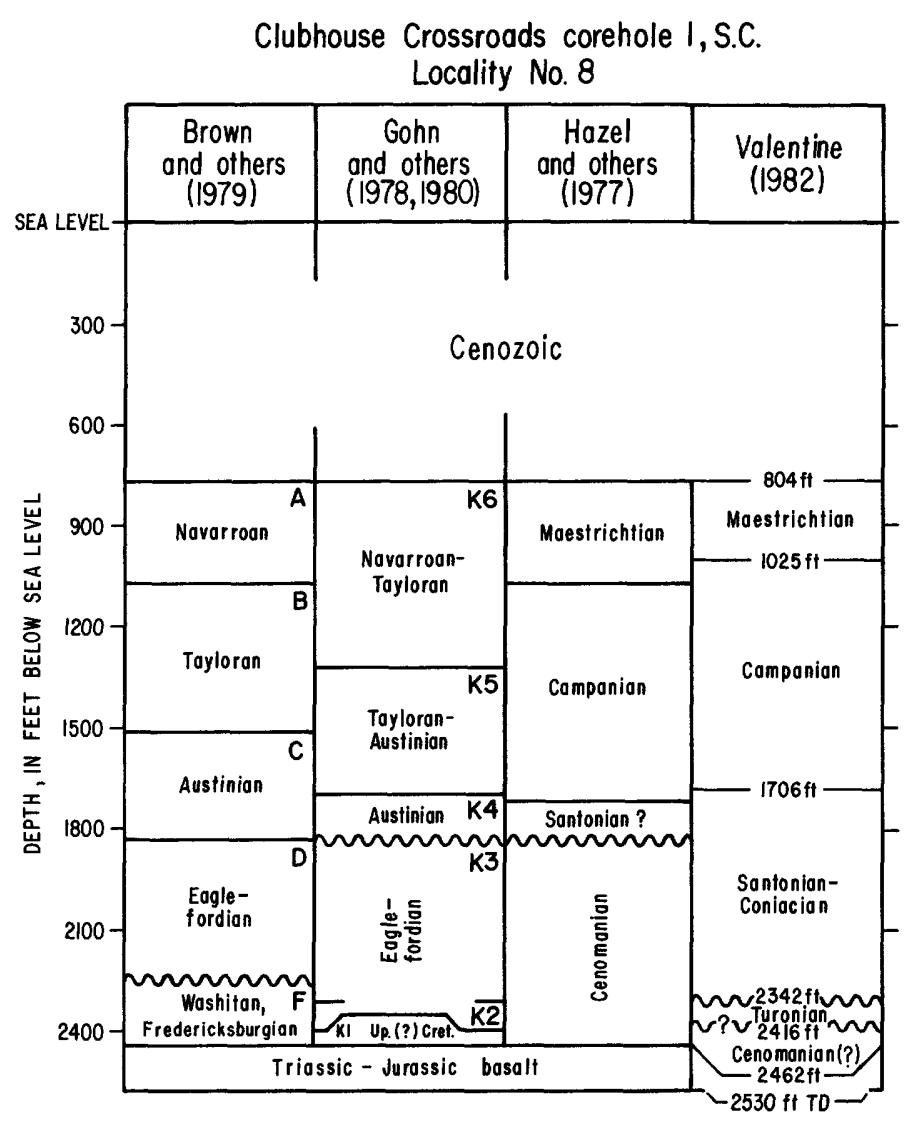

Figure 5.-Stratigraphic interpretations of Clubhouse Crossroads corehole 1, South Carolina. Depth scale is relative to sea level; stratigraphic boundaries are given in original depths (for depth below sea level, subtract $23 \mathrm{ft}$ ). Wavy lines indicate unconformities. 
nannofossils, and the presence of Eiffellithus eximius, Tetralithus obscurus, and Lithastrinus grillii point to a Turonian age or younger, possibly Coniacian. Planktic foraminifers are sparse in the interval from 1,706 to $2,342 \mathrm{ft}$; two samples $(1,922.5$ and $2,308.8 \mathrm{ft})$ examined by C. C. Smith (unpub. data, 1976) each contained a single species (Globigerinelloides caseyi and G. sp. ef G. caseyi, respectively) and were dated as Cenomanian. G. caseyi, however, is not restricted to the Cenomanian; its highest occurrence is considered by Ascoli (1976) to be diagnostic of lower Turonian strata beneath the Scotian Shelf of Canada. It is present also in the upper Cenomanian and lower and middle Turonian of Kansas and Colorado (Eicher and Worstell, 1970). The beds from 1,706 to $2,342 \mathrm{ft}$ are chiefly sand. and silt, and Gohn and others (1978, sheet 2) correlated this interval, which they identified as units $\mathrm{K} 3$ and $\mathrm{K} 4$, with a lithologically similar sequence in the Fripp Island well that I have determined to be SantonianConiacian in age.

Lower in the Clubhouse Crossroads core, a spore and pollen flora characteristic of the ComplexiopollisAtlantopollis pollen zone and the Woodbridge Clay Member of the Raritan Formation of New Jersey is present at 2,342.3, 2.371.1, 2,375.0, and 2,404.8 ft (Hazel and others, 1977). On the other hand, samples from these beds $(2,364.4,2,365.4,2,369.4,2,373.7$, and $2,399.2 \mathrm{ft}$ ) contain planktic foraminifers interpreted to be Cenomanian in age (C. C. Smith, unpub. data, 1976). Guembelitria harrisi, Hedbergella brittonensis, and Heterohelix moremani are the only species present, and the age is based on the presence of Guembelitria harrisi. The range of this species, however, is not precisely known, and it is probably present in the Turonian as Eicher and Worstell (1970) have shown it to range higher than Rotalipora in sections in Colorado, Wyoming, and South Dakota. Three other samples $(2,367.5$, $2,370.5$, and $2,396.0 \mathrm{ft}$ ) from this part of the core yielded only Guembelitria harrisi and Heterohelix moremani (C. W. Poag, unpub., data, 1981).

Hattner and Wise (1980) studied nannofossils from the Upper Cretaceous of the Clubhouse Crossroads core. Among four samples from the Complexiopollis-Atlantopollis interval, all but one are barren or contain nondiagnostic floras; at $2,373 \mathrm{ft}$, Ahmuellerella octoradiata, Lithraphidites acutum, and L. alatus are present in an assemblage they interpreted to be Cenomanian.

I have examined the nannofossils from the same part of the core, and 38 of 80 samples in the $68.4-\mathrm{ft}$ interval from $2,338.5$ to $2,407.0 \mathrm{ft}$ are fossiliferous (fig. 6 ). The ranges of biostratigraphically important species are Ahmuellerella octoradiata $(2,375-2,407 \mathrm{ft})$; Corollithion achylosum (2,363.5-2,407 ft); Cruciellipsis chiastia (2,364.5-2,406 ft); Eiffellithus eximius

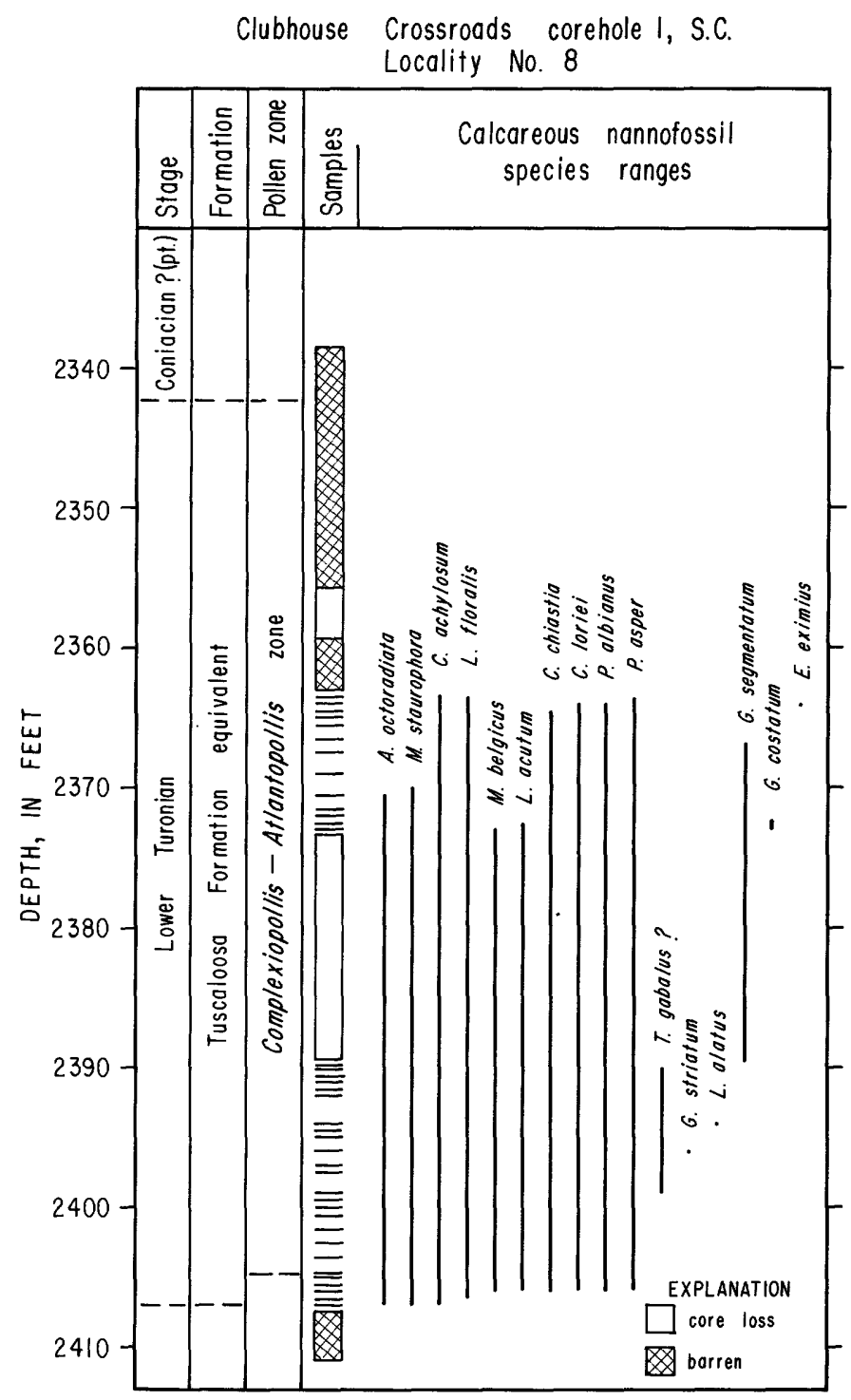

FIGURE 6.-Turonian stratigraphy, calcareous nannofossil ranges, and occurrence of the Complexiopollis-Atlantopollis zone in the Clubhouse Crossroads corehole 1, South Carolina. Pollen stratigraphy from Hazel and others (1977). Depth scale is original depth.

(rare, 2,364 ft); Lithraphidites acutum (2,372.5-2,406 ft); L. alatus (rare, 2,394.5 ft); Microrhabdulus belgicus (rare, 2,373 and 2,406 ft); Micula staurophora (rare, 2,370-2,407ft); and Podorhabdus albianus (2,364-2,406 $\mathrm{ft})$. These strata are unit K2 of Gohn and others (1978) who have shown them to be coeval with K2 in the Fripp Island well that also contains a ComplexiopollisAtlantopollis zone flora and Turonian nannofossil assemblages. Brown and others (1979) indicated that their unit $\mathrm{E}$ is missing from the Clubhouse Crossroads section but that the older unit $\mathrm{F}$ is present. The evidence presented here and in the discussion of the Parris Island well suggests that unit $F$ in the Clubhouse Crossroads core is equivalent to unit $\mathrm{E}$ at Parris Island 
and that, in these two wells, they are correlative with unit K2 of Gohn and others (1978). Between these strata and basalt at $2,462 \mathrm{ft}$, there lies a thin, undated interval that is practically barren, which could be Cenomanian in age.

\section{AGES OF SUBSURFACE STRATIGRAPHIC UNITS IN SOUTH CAROLINA}

The analyses of the Parris Island, Fripp Island, and Clubhouse Crossroads sections are, in part (see Valentine, 1982), the basis for a reevaluation of the ages of previously described stratigraphic units in the subsurface of coastal South Carolina (fig. 7). I agree with the ages assigned by Brown and others (1979) to their units A (Navarroan) and B (Tayloran), but I observe some overlap of the two units at the NavarroanTayloran (Maestrichtian-Campanian) boundary. I restrict their unit C (Austinian) to the upper Austinian (Campanian-Santonian), and I now assign their unit D (Eaglefordian) to the middle and lower part of the Austinian (Santonian-Coniacian) and unit E (Woodbinian) to the Eaglefordian (Turonian). Units $\mathrm{E}$ and F (Washitan and Fredericksburgian) may be delineated inadequately in South Carolina, because beds that are identified as Unit $\mathrm{E}$ in the Parris Island well are correlative, in my opinion, to unit $\mathrm{F}$ at Clubhouse Crossroads (Brown and others, 1979). It appears that the upper part of unit $F$ can be assigned to the lower Turonian (Eaglefordian) in this region.

The ages of the stratigraphic units of Gohn and others $(1978,1980)$ that represent Maestrichtian, Campanian, and Santonian strata (units K6, K5, and K4) remain unchanged in my interpretation. Those authors, however, recognized a Coniacian-Turonian hiatus in the section, and they placed units $\mathrm{K} 2$ and $\mathrm{K} 3$ in the upper Cenomanian and placed unit K1 in the Upper(?) Cretaceous. In contrast, I believe that Santonian, Coniacian, and lower Turonian strata are present beneath the South Carolina coast. In my interpretation, unit K3 represents the Coniacian and possibly part of the Santonian (lower Austinian), whereas unit K2 is lower Turonian (middle and upper Eaglefordian). Unit $\mathrm{K} 1$ is present only in the lowest part of the sedimentary section and may be unfossiliferous; Cenomanian beds, if present, are poorly represented in the interval just above pre-Cretaceous basement rocks.

\section{GEORgia COASTAL PLAIN}

\section{GEORGIA GEOLOGICAL SURVEY WELLS 1197, 724, 1198}

In Georgia, three wells located in the center of the Southeast Georgia Embayment onshore (fig. 1) have penetrated strata near basement that contain floras characteristic of the Complexiopollis-Atlantopollis pollen zone (Valentine, 1982). Brown and others (1979)

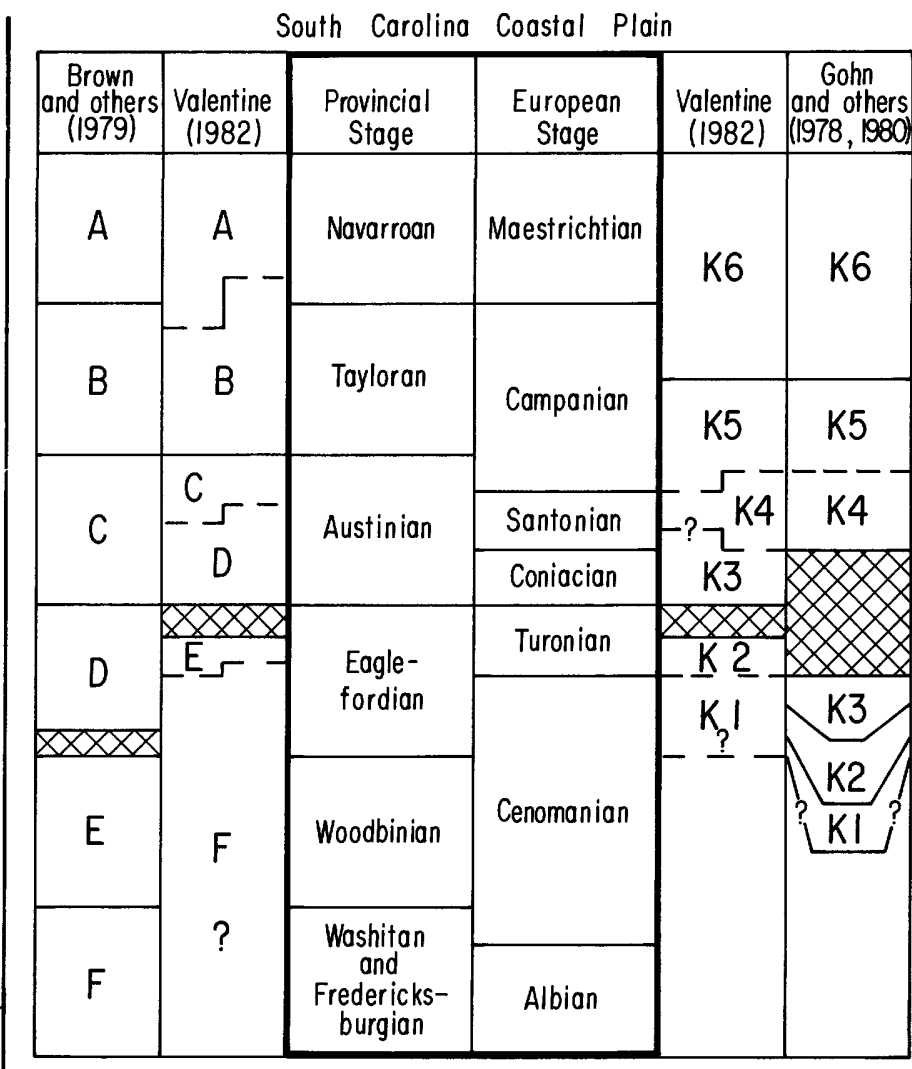

FIGURE 7.-Cretaceous stratigraphic units recognized in the subsurface of coastal South Carolina by Gohn and others $(1978,1980)$ and by Brown and others (1979). Correlation of the units with European and Provincial Stages, as shown by those authors, is compared to the interpretations of Valentine (1982) and the present study. Crosshatched areas represent hiatuses. Dashed lines indicate uncertain delineation of unit boundaries with respect to European and Provincial Stages.

and Gohn and others (1980) studied these wells as part of their stratigraphic interpretations of the region. Complexiopollis and Atlantopollis are present together in cuttings from 4,500 to 4,530 and 4,590 to $4,620 \mathrm{ft}$ in Georgia Geological Survey (GGS) well 1198 (R. A. Christopher, unpub. data, 1978). These samples are from units $E$ and $F$ of Brown and others (1979) and from unit K 2-3 of Gohn and others (1980). A sample from 4,530 to $4,560 \mathrm{ft}$ yielded nannofossils and planktic foraminifers that were interpreted to be Cenomanian in age (C. C. Smith, unpub. data, 1978). The nannofossil assemblage from this sample appears to me to be Turonian, on the basis of the presence of Corollithion achylosum, Eiffellithus eximius, Lithraphidites alatus, Parhabdolithus asper, and Podorhabdus albianus. The foraminifers of stratigraphic importance in the sample range across the Cenomanian-Turonian boundary; Guembelitria harrisi is present, but, as previously mentioned, it is not a reliable marker for the Cenomanian.

GGS 724 also yielded Complexiopollis and Atlantopollis in cuttings samples 4,520 to 4,540 and 4,630 to 
4,640 ft (R. A. Christopher, unpub. data, 1978) from unit $F$ (Brown and others, 1979) and from unit K2 (Gohn and others, 1980). In GGS 1197, a similar flora is present at 4,180 to 4,190 ft (R. A. Christopher, unpub. data, 1979) from units $\mathrm{E}$ and $\mathrm{K} 2$.

\section{TEXAS COASTAL PLAIN}

\section{SOCONY MOBIL COREHOLE 16}

The biostratigraphic relations from the Atlantic Coastal Plain are also evident in a core from the Gulf Coastal Plain at Dallas, Tex. (figs. 2 and 8, SoconyMobil Field Research Lab corehole 16; Brown and Pierce, 1962; Pessagno, 1969; Christopher, 1982). In the Dallas core, a Complexiopollis-Atlantopollis zone flora is present in the middle and upper part of the Britton Formation and in the lower part of the Arcadia Park Formation of the Eagle Ford Group, whereas, lower in the Eagle Ford Group, the pollen flora contains rare Complexiopollis but no Atlantopollis and is assigned to the post-zone III, pre-ComplexiopollisAtlantopollis zone interval (Christopher, 1982). A similar floral break occurs just above the CenomanianTuronian boundary in the Toms River well in New Jersey.

My study of the calcareous nannofossils from the Dallas core shows that Eiffellithus eximius and Corollithion achylosum are present together in the uppermost part of the Britton Formation and range through the Arcadia Park Formation, indicating a Turonian age for these strata. The upper part of this interval (middle and upper Arcadia Park Formation) contains a post-Complexiopollis-Atlantopollis, pre-zone $\mathrm{V}$ flora and is late Turonian in age. The lower part of the interval (uppermost Britton Formation and lowermost Arcadia Park Formation) lies in the upper part of the Complexiopollis-Atlantopollis zone in this core and is early Turonian in age. Lithraphidites acutum, a species that ranges from the Cenomanian into the lower Turonian, is present in the middle and lower Complexiopollis-Atlantopollis zone (middle and upper Britton Formation). It is also present with the Normapolles genus Complexiopollis in the lower Britton Formation, which is probably Cenomanian in age.

In a previous study of the Dallas core based in planktic foraminifers, Pessagno (1969, pl. 9) concluded that the Britton and Arcadia Park Formations represent upper Cenomanian and upper Turonian strata separated by a lower Turonian hiatus; he interpreted the Cenomanian-upper Turonian boundary to lie near the top of the Britton Formation, between about 213 and $223 \mathrm{ft}$. However, planktic foraminifers are not well represented in the core, and the stratigraphically important genus Rotalipora is present in only one sample at $444 \mathrm{ft}$ (Pessagno, 1969, pl. 39b).

J. D. Powell (in Christopher, 1982; oral and written commun., 1980,1982) studied the mollusks and foraminifers from an equivalent section in an outcrop near the Dallas core site and concluded that the upper $15 \mathrm{ft}$ of the Britton Formation and possibly the lower $30 \mathrm{ft}$ of the Arcadia Park Formation represent the Mytiloides "labiatus" zone of early Turonian age (fig. 9). Below this zone, in the middle and upper part of the Britton Formation, Powell delineated the Sciponoceras gracile zone that I believe overlaps the Cenomanian-Turonian boundary. Regarding the range of Rotalipora, Powell (1970) found that the upper limit of abundant Rotalipora is at the top of a chalky interval at outcrop locality D2 and that this level is also the base of the Sciponoceras gracile zone in outcrop and is coincident with the top of the bentonitic interval in corehole 16. Powell also found rare rotaliporids ranging up to the Metoicoceras whitei and Inoceramus pictus level at locality D3. The Arcadia Park Formation at outcrop locality D3 and in the Dallas corehole several miles to the east is almost equal in thickness. The Britton Formation is not fully exposed at D3, but, assuming that the exposed section and an equal thickness of the Britton in the corehole are coeval, the top of the Rotalipora range should occur at about $270 \mathrm{ft}$ in corehole 16 . On the same basis, the top of the Mytiloides "labiatus" zone and the associated lower Turonian-upper Turonian boundary are placed provisionally $30 \mathrm{ft}$ above the base of the Arcadia Park Formation (fig. 9). The placement of this datum is not well documented, and it probably lies higher in the section, above the top of the Complexiopollis-Atlantopollis zone. At present, a case cannot be made for extending the ComplexiopollisAtlantopollis zone into the upper Turonian.

On the basis of the results of the studies on the Dallas core and the age established for the Complexiopollis-Atlantopollis zone beneath the northern Atlantic Coastal Plain, I have concluded that upper and lower Turonian strata are present in the section that encompasses the upper Britton Formation and the Arcadia Park Formation. In a previous paper (Valentine, 1982), written before I knew the details of Powell's work on Rotalipora, I drew the Cenomanian-Turonian boundary at the base of the Complexiopollis-Atlantopollis pollen zone in the Dallas core. Now I place the Cenomanian-Turonian boundary at the last occurrence of Rotalipora in outcrop and at the equivalent level in the core as described above. This is somewhat below the boundary selected by Christopher (1982) at the top of the Sciponoceras gracile zone, and it is above the boundary recognized by Brown and Pierce (1962). 
TEXAS COASTAL PLAIN

Socony Mobil corehole 16, Dallas, Tex.

Locality No. 15

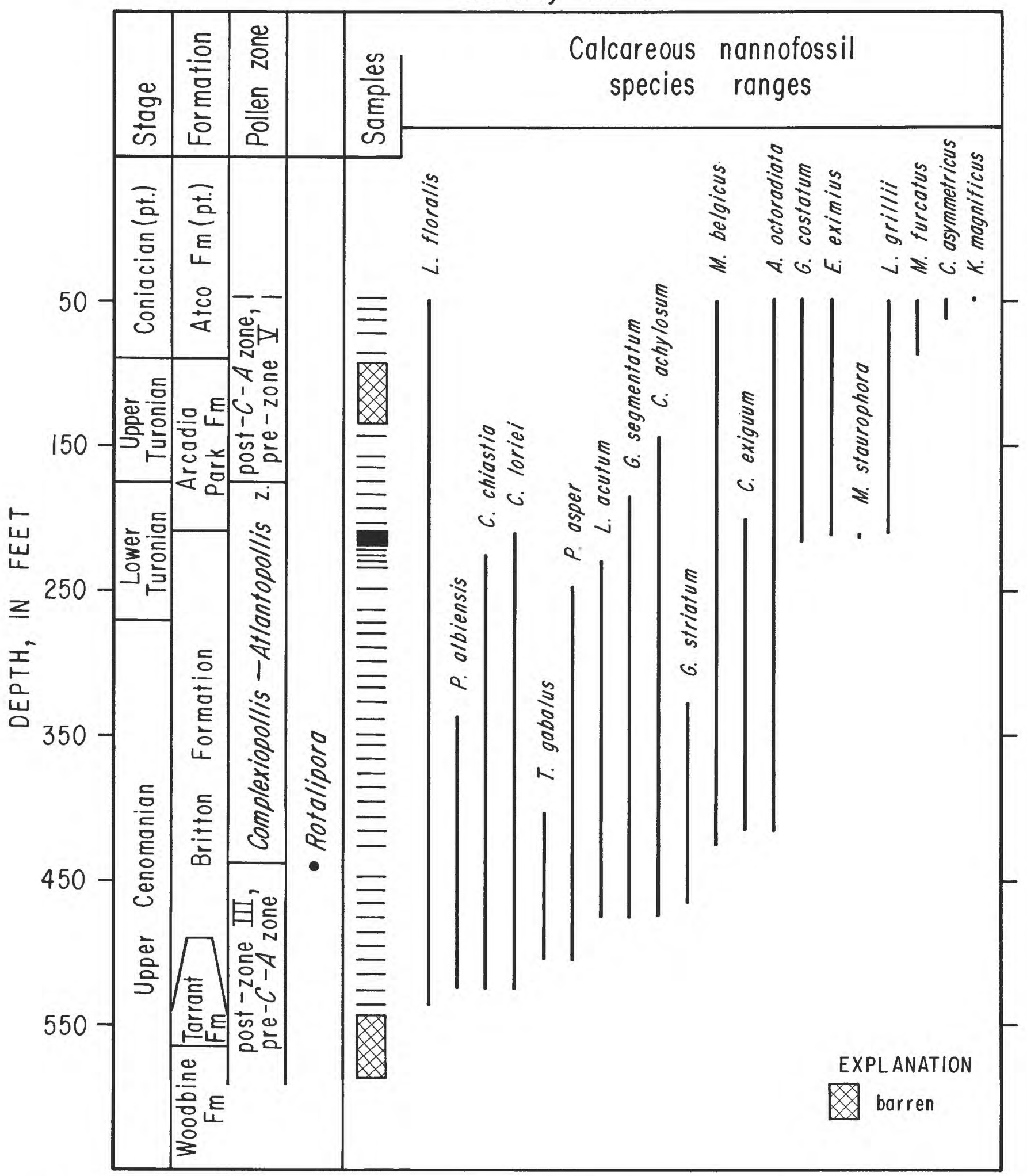

FIGURE 8.-Upper Cenomanian, Turonian, and Coniacian stratigraphy, calcareous nannofossil ranges, and occurrence of the Complexiopollis-Atlantopollis and adjacent zones in the Socony Mobil corehole 16, Dallas, Tex. Pollen stratigraphy from Christopher (1982). Single occurrence of Rotalipora from Pessagno (1969). Depth scale is original depth. 
FIGURE 9.-Correlation of biostratigraphic and lithostratigraphic units of the Atlantic Coastal Plain and Texas. The Rotalipora extinction is a datum. Unit K2, a distinctive stratigraphic unit, is correlated in GGS 724, GGS 1197, Parris Island No. 2, Fripp Island, and Clubhouse Crossroads corehole 1 with the lower Turonian. The placement of the lower Turonian-upper Turonian boundary is uncertain, but it proba- bly lies above the top of the Complexiopollis-Atlantopollis zone in the Dallas corehole. The top of the Complexiopollis-Atlantopollis pollen zone is correlated with the top of the lower Turonian in Clubhouse Crossroads corehole 1 and in the E. G. Tavlor No. 1-G, Toms River, Fire Island State Park, Martha's Vineyard, and Nantucket wells. Stratigraphic units are to scale at each locality. No horizontal scale.

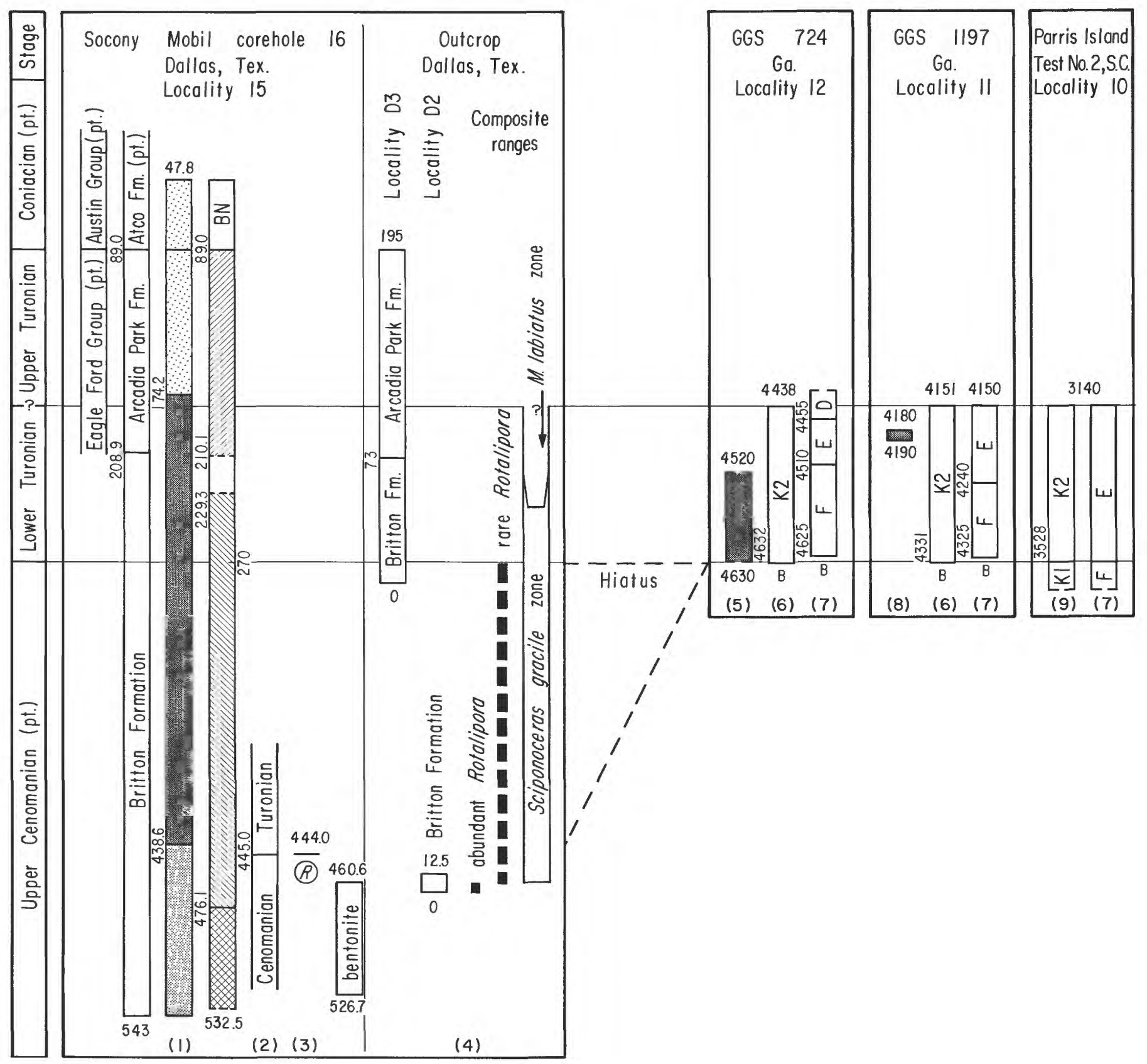


Depths are original depths in feet. Sources of data are (1) Christopher, 1982; (2) Brown and Pierce, 1962; (3) Pessagno, 1969; (4) Powell, 1970; personal commun., 1981, 1982; (5) Christopher, unpub. data, 1978; (6) Gohn and others, 1980; (7) Brown and others, 1979; (8) Christopher, unpub. data, 1979; (9) Gohn and others, 1978; (10) Chris- topher, unpub. data, 1979; (11) Hazel and others, 1977; (12) Robbins and others, 1975; (13) Christopher, oral commun., 1979; (14) Petters, 1976; (15) Brown and others, 1972; (16) Doyle, 1969b; oral commun., 1981; (17) Sirkin, 1974; (18) Hall and others, 1980; (19) Folger and others, 1978.

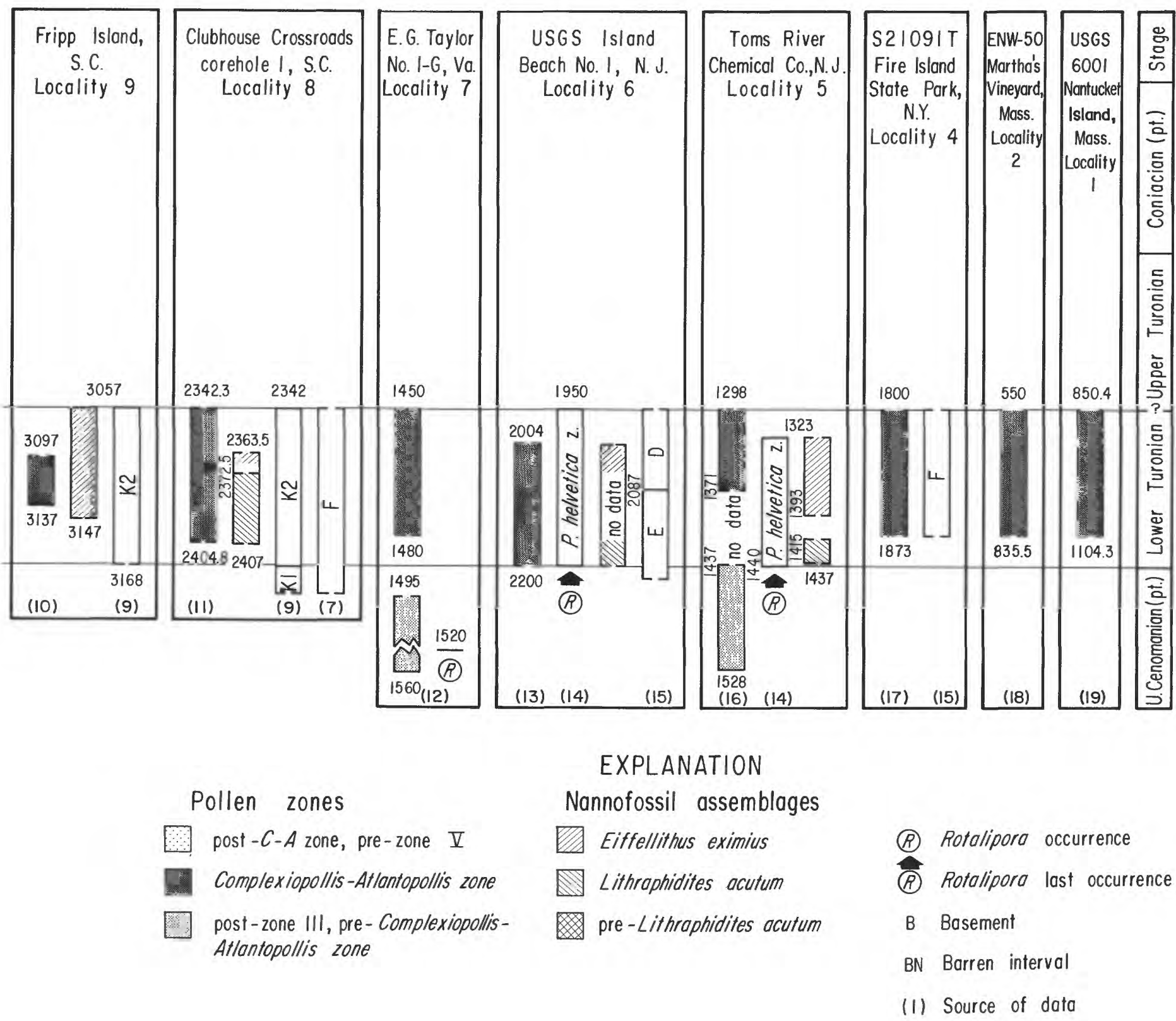




\section{CORRELATION OF TURONIAN AGE STRATIGRAPHIC UNITS OF THE ATLANTIC AND GULF COASTAL PLAINS}

The Complexiopollis-Atlantopollis zone is present in Coastal Plain strata extending from New England to Texas. This zone and its associated foraminifer and calcareous nannofossil assemblages play an important role in dating and revising the ages of formations beneath the Atlantic and Gulf Coastal Plains (fig. 9). At Dallas, Tex., upper Cenomanian and lower and upper Turonian strata are present in a seemingly uninterrupted section that lies unconformably beneath Coniacian beds of the Austin Group. Stratigraphic evidence based on the occurrences of mollusks and foraminifers from outcrops that are correlated with the corehole section indicates that the ComplexiopollisAtlantopollis zone and the Lithraphidites acutum nannofossil assemblage are present in the upper Cenomanian and lower Turonian and that the Eiffellithus eximius assemblage succeeds the Lithraphidites acutum assemblage in the lower Turonian.

Beneath the Atlantic Coastal Plain, in the Salisbury and Raritan Embayments, pollen, foraminifers, and calcareous nannofossils from several localities have been studied. In the Toms River well, New Jersey, the pollen stratigraphy is incomplete, but the evidence suggests that the base of the ComplexiopollisAtlantopollis zone lies within the lower Turonian Praeglobotruncana helvetica zone, as does the boundary between the Lithraphidites acutum and Eiffellithus eximius assemblages. The stratigraphy at the Island Beach well is similar, except that a Complexiopollis-Atlantopollis assemblage is present at the base of the $P$. helvetica zone where Rotalipora becomes extinct, and it is possible that the ComplexiopollisAtlantopollis zone extends below the CenomanianTuronian boundary here. In the E. G. Taylor well on the eastern shore of Virginia, the base of the Complexiopollis-Atlantopollis zone lies in beds that have yielded poorly preserved planktic foraminifers tentatively dated as pre-Santonian to Cenomanian in age; Rotalipora is present in the deepest sample studied, within the late Cenomanian post-zone III, pre-Complexiopollis-Atlantopollis zone interval.

Therefore, the Complexiopollis-Atlantopollis zone appears to be early Turonian in age on the flanks of the Raritan and Salisbury Embayments. The upper Cenomanian part of this pollen zone possibly is missing there, but it could be present in deeper areas of the basins. The Fire Island, Martha's Vineyard, and Nantucket wells are located near the landward edge of the Coastal Plain on the Long Island Platform, and, because the Complexiopollis-Atlantopollis strata lie at relatively shallow depths in these wells, I am assigning them an early Turonian age.

South of the Cape Fear Arch, the ComplexiopollisAtlantopollis zone is present in a distinctive lithologic unit in a series of wells that transects the northern flank and central region of the Southeast Georgia Embayment(fig. 9). At Fripp Island, a Complexiopollis-Atlantopollis flora and the Turonian Eiffellithus eximius assemblage are present in an interval described as unit K2 by Gohn and others $(1978,1980)$. Unit $\mathrm{K} 2$ is lithologically variable, but it is a relatively thin unit of approximately formational rank near the base of the Upper Cretaceous sequence, widespread beneath the coasts of South Carolina and Georgia. At Clubhouse Crossroads, somewhat higher on the flank of the basin, the Complexiopollis-Atlantopollis, Eiffellithus eximius, and Lithraphidites acutum assemblages are all present in unit K2. I interpret unit K2 to be early Turonian in age, equivalent to the upper part of the Britton Formation and the lower part of the Arcadia Park Formation at Dallas. In the Georgia subsurface, the Complexiopollis-Atlantopollis zone is present in unit K2 in two wells in Glynn County.

Along the Atlantic Coast from New York to Georgia, the lower Turonian correlates variously with "chronostratigraphic" units D, E, and F of Brown and others $(1972,1979)$. Unit $F$, in particular, has been recognized in many wells by the presence of an ostracode fauna that includes the species Fossocytheridea lenoirensis, which has been reported from 38 wells in North Carolina and in 1 well in southern Virginia (Brown and others, 1972; Swain and Brown, 1972). At present, nannofossil, foraminifer, and pollen assemblages from unit $\mathrm{F}$ in these wells cannot be compared, but some evidence indicates that beds containing $F$. lenoirensis are Turonian in age. In the Clubhouse Crossroads corehole 1, South Carolina, F. lenoirensis is present at 2,365 $\mathrm{ft}$ (Hazel and others, 1977), and I have observed it at $2,367.5 \mathrm{ft}$. Both occurrences are within the interval $(2,342.3-2,404.8 \mathrm{ft})$ where calcareous nannofossils that I interpret to be Turonian in age are present with Complexiopollis-Atlantopollis pollen. In addition, a Complexiopollis-Atlantopollis flora is present in a core provided by P. M. Brown from unit F in a well from Halifax County, N.C., near the type section for unit F (Christopher and others, 1979; Christopher, oral commun., 1981).

The foregoing biostratigraphic analysis has led to a new, albeit provisional, correlation of Coastal Plain formations and informal lithologic units with the Eaglefordian Provincial Stage (fig. 10). In the Raritan Embayment of northern New Jersey, the Complexiopollis-Atlantopollis zone encompasses the Wood- 


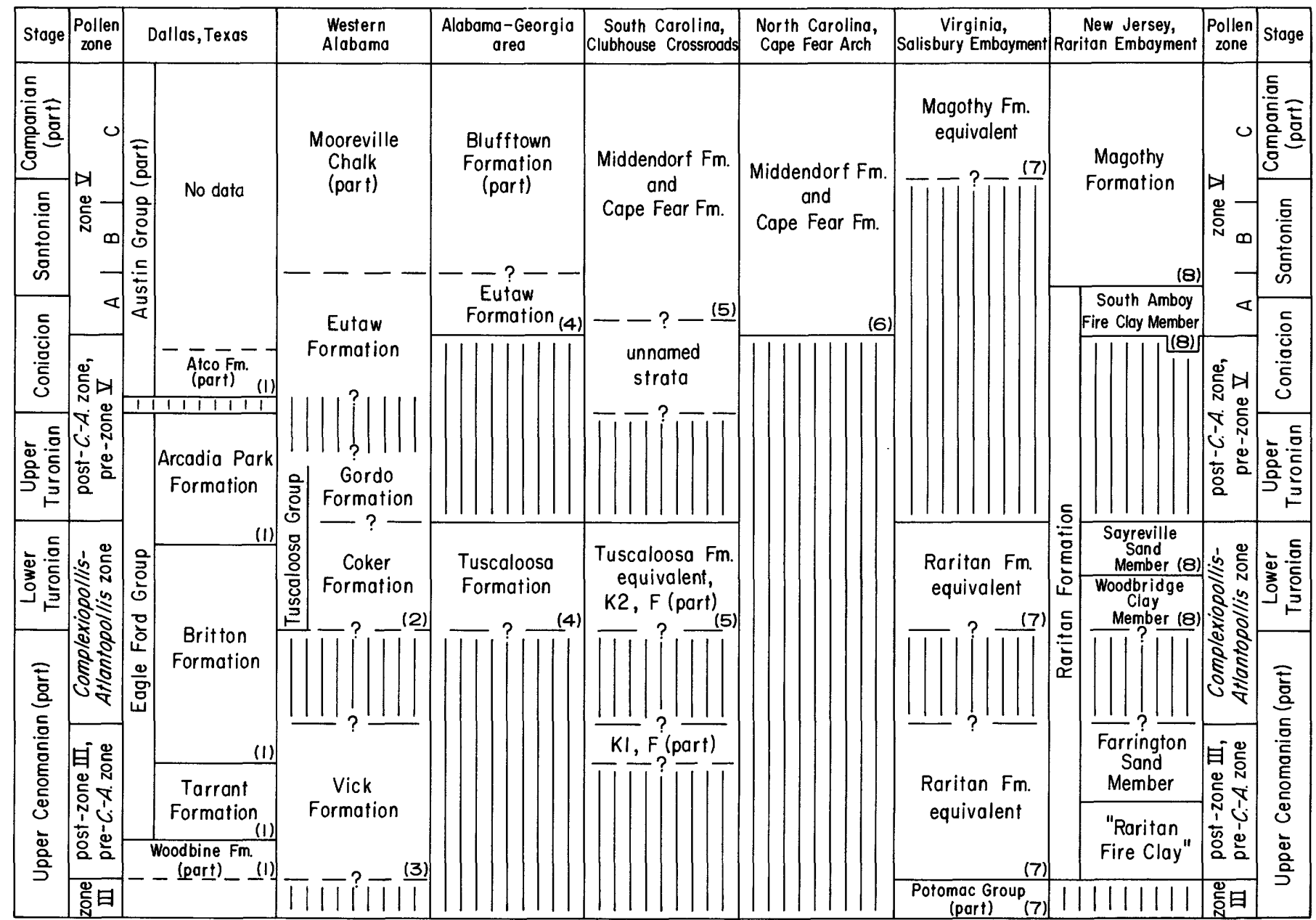

Figure 10.-Generalized correlation chart for upper Cenomanian to lower Campanian strata of the Atlantic and Gulf Coastal Plains. Ages of Turonian and upper Cenomanian units based on nannofossils, planktic foraminifers, and pollen as discussed in text. Assignment of numbered units to pollen zones is based on (1) Christopher, 1982; (2) Christopher and others, 1979; (3) Christopher, 1972; (4) Christopher, 1979b, 1982; oral commun., 1978; (5) Hazel and others, 1977; Christopher and others, 1979; Christopher, oral commun., 1979; (6) Christopher and others, 1979; (7) Robbins and others, 1975; Doyle and Robbins, 1977; Ruth Todd, unpub. data, 1973; (8) Christopher, 1979a, 1982, oral commun., 1979. Placement of the Blufftown Formation, the Mooreville Chalk, and the Eutaw Formation of western Alabama from Hazel and others, 1977, fig. 3. Units K1 and K2 described by Gohn and others, 1978, 1980. Unit F described by Brown and others, 1972, 1979. Ruled lines indicate hiatuses. Not to scale.

bridge Clay and the Sayreville Sand Members of the Raritan Formation (Christopher, 1979a), and I assign them to the lower Turonian. They are separated by a hiatus from the South Amboy Fire Clay Member that Christopher (1979a, 1982, oral commun., 1979) placed in pollen zone V-A of the Coniacian-Santonian age. The lower members of the Raritan Formation, the informal "Raritan Fire Clay," and the Farrington Sand Member are more difficult to date. The palynomorphs of this part of the outcropping Raritan are known only from a single sample from the "Raritan Fire Clay" (Groot and others, 1961). The flora does not contain Complexiopollis or Atlantopollis, but Doyle and Rob- bins (1977) placed it in zone IV, apparently because it is more typical of that zone than of the older zone III. I provisionally assign the "Raritan Fire Clay" and the Farrington Sand Member to the post-zone III, preComplexiopollis-Atlantopollis zone interval of late Cenomanian age that Christopher (1982) identified in the Dallas, Tex., corehole. An unconformity may exist between the Farrington Sand and the overlying Woodbridge Clay Members, representing the upper Cenomanian part of the Complexiopollis-Atlantopollis zone that apparently is missing beneath the Atlantic Coastal Plain.

On the eastern shore of Virginia, the E. G. Taylor 
No. 1-G well in the Salisbury Embayment penetrated strata that are equivalent to the Raritan Formation of New Jersey (Robbins and others, 1975; Doyle and Robbins, 1977). The upper beds in the sequence contain a Complexiopollis-Atlantopollis zone flora and are coeval with the Woodbridge Clay and Sayreville Sand Members of early Turonian age. Lower in the section and possibly separated by a hiatus, slightly older beds contain only Complexiopollis of the Normapolles group, and I assign them to the post-zone III, pre-Complexiopoll is-Atlantopollis zone interval of late Cenomanian age. A hiatus encompassing late Turonian and possibly Coniacian time separates the Raritan age section from an overlying sequence of Magothy age.

In South Carolina, south of the Cape Fear Arch, the Complexiopollis-Atlantopollis zone is present in Clubhouse Crossroads corehole 1 . The flora is in strata corresponding to unit K2 of Gohn and others (1978) and to part of unit F of Brown and others (1979). These beds are palynologically equivalent to the Tuscaloosa Formation of eastern Alabama and western Georgia. This part of the section at Clubhouse Crossroads previously had been equated with the Cape Fear Formation (Hazel and others, 1977), but recent work by Christopher and others (1979) on the Cape Fear Arch in North Carolina has shown that the Cape Fear Formation contains a flora typical of pollen zone $\mathrm{V}$ of Coniacian-Campanian age. At Clubhouse Crossroads, the Cape Fear Formation is actually represented by beds much higher in the core, which Hazel and others (1977) correlated with the South Amboy Fire Clay Member and the Magothy Formation of New Jersey. The lower Turonian at Clubhouse Crossroads probably is separated by an upper Turonian hiatus from a sequence of undated and unnamed beds, possibly of Coniacian age. Though the beds below the lower Turonian are not dated (unit K1 and the lowest part of unit F), they are placed provisionally in the Cenomanian.

In the Alabama-Georgia region of the eastern Gulf Coastal Plain, the Complexiopollis-Atlantopollis zone has been identified in the Tuscaloosa Formation, and pollen zone V-A of Coniacian-Santonian age has been reported from the overlying Eutaw Formation (Christopher, 1979b, 1982, oral commun., 1978). The Tuscaloosa Formation in eastern Alabama and western Georgia is placed provisionally in the lower Turonian, and it is separated by an upper Turonian-lower Coniacian hiatus from the Eutaw Formation. In western Alabama, a Complexiopollis-Atlantopollis flora is present in the Coker Formation, the basal formation of the Tuscaloosa Group (Christopher and others, 1979). The overlying Gordo Formation is not well known palynologically, but Leopold and Pakiser (1964) studied a core sample that contained pollen species of Turonian affinity, and they interpreted the Tuscaloosa Group and the overlying McShan and Eutaw Formations to be pre-Coniacian in age. I provisionally place the Coker Formation in the lower Turonian, but it could extend into the upper Cenomanian. The Gordo Formation is probably Turonian in age, but further work is necessary to determine whether it is part of the Complexiopollis-Atlantopollis zone or whether it could represent the post-Complexiopollis-Atlantopollis zone, pre-zone $\mathrm{V}$ interval of late Turonian to Coniacian age that is missing beneath the Coastal Plain to the east. The Vick Formation underlies the Tuscaloosa Group in western Alabama. It has been dated as late Cenomanian by Christopher (1972) who considered it to be a sedimentary facies of the Coker Formation. The Vick flora must be clarified before its stratigraphic position can be determined accurately, and I have tentatively assigned it to the post-zone III, pre-ComplexiopollisAtlantopollis zone interval of late Cenomanian age.

In the Eagle Ford section at Dallas, Tex., the Tarrant, Britton, and Arcadia Park Formations represent a relatively complete sequence of late Cenomanian and Turonian age. The Tarrant Formation and the lower part of the Britton Formation are equivalent to the lower part of the Raritan Formation in New Jersey. The middle part of the Britton Formation and the corresponding upper Cenomanian part of the Complexiopollis-Atlantopollis zone probably is missing from most areas of the Atlantic Coastal Plain. The upper Britton Formation and the lowermost Arcadia Park Formation correlate with the Woodbridge Clay and Sayreville Sand Members of the Raritan. The bulk of the Arcadia Park Formation represents an interval that is missing in New Jersey, as pointed out by Christopher (1982). The hiatus at the Turonian-Coniacian boundary at Dallas is expanded in the Raritan Embayment of northern New Jersey to encompass an upper Turonian and perhaps lower Coniacian gap between the Sayreville Sand and the South Amboy Fire Clay Members. However, in the Salisbury Embayment in southernmost New Jersey, both the upper Turonian and Coniacian are reported to be present in the Anchor Gas, Dickinson No. 1 well (Petters, 1976, p. $97)$.

\section{SUMMARY AND CONCLUSIONS}

In this study I have sought to resolve the age of a stratigraphic interval beneath the Atlantic and Gulf Coastal Plains that is characterized by the occurrence of distinctive calcareous nannofossil and pollen assemblages. The biostratigraphy is based on the ranges of the key nannofossil species Corollithion achylosum, Eiffellithus eximius, and Lithraphidites acutum, on the occurrence of the widespread ComplexiopollisAtlantopollis pollen assemblage zone, and on the assumption that the extinction of the planktic fora- 
minifer genus Rotalipora marks the CenomanianTuronian boundary.

The Complexiopollis-Atlantopollis pollen zone is present beneath the Atlantic Coastal Plain from New England to Georgia and at localities in Alabama and Texas on the Gulf Coast. One or both of the Eiffellithus eximius and Lithraphidites acutum nannofossil assemblages are found in this pollen zone in wells in New Jersey, South Carolina, and Texas. Planktic foraminifers are present also with these nannofossil and pollen floras in New Jersey and support an age of early Turonian for the interval in question. In Texas, planktic foraminifers and mollusks indicate that the Complexiopollis-Atlantopollis zone ranges from uppermost Cenomanian to lower Turonian.

The dating of the Complexiopollis-Atlantopollis zone as early Turonian beneath the Atlantic Coastal Plain has resulted in a revision of the ages of established stratigraphic units and suggests the existence there of a hiatus representing the uppermost Cenomanian.

The following lithologic units are assigned to the lower Turonian (Eaglefordian): the Woodbridge Clay and Sayreville Sand Members of the Raritan Formation, New Jersey; the upper part of the Raritan equivalent in the E. G. Taylor No. 1-G well on the eastern shore of Virginia; the Tuscaloosa equivalent (units K2, E, and part of F) in the South Carolina and Georgia coastal region; the Tuscaloosa Formation of eastern Alabama and western Georgia; and the Coker Formation of the Tuscaloosa Group in western Alabama. Farther north, the lower Turonian encompasses parts of units D and E in a well in New Jersey, whereas it corresponds to part of unit $F$ in a well on Fire Island.

The Eagle Ford Group at Dallas, Tex., contains strata of late Cenomanian and early and late Turonian age. The Tarrant Formation and the lower and middle parts of the Britton Formation are late Cenomanian in age. The upper Britton and lowermost Arcadia Park Formations are early Turonian, and the remainder of the Arcadia Park is late Turonian in age.

Hiatuses in the stratigraphic record of the Atlantic Coastal Plain are pronounced on the flanks of embayments, but determining their extent throughout a sedimentary basin is sometimes difficult. Lower Turonian strata appear to be present all along the Atlantic coastal region, and they probably lie disconformably on upper Cenomanian beds. In contrast, the upper Turonian is represented by a hiatus in many areas. It is absent in the Raritan Embayment of New Jersey and in the southern part of the Salisbury Embayment in Virginia, but upper Turonian strata are reported in the central part of the Salisbury Embayment at Cape May, N.J. On the Cape Fear Arch in North and South Carolina, the Cenomanian and Turonian Stages apparently are absent. In the Southeast Georgia Embay- ment, the upper Turonian is absent also, and the lower Turonian is bounded below by a thin interval of undated sedimentary rocks of possible Cenomanian age that overlie crystalline basement.

Turonian and adjacent strata are better represented beneath the Gulf Coastal Plain. In western Alabama, the lower Turonian Coker Formation lies between the upper Cenomanian Vick Formation and the Gordo Formation of possible late Turonian age. At Dallas, Tex., the upper Cenomanian and lower and upper Turonian are present in a relatively uninterrupted section, separated by a hiatus from the Coniacian part of the Austin Group.

\section{REFERENCES CITED}

Ascoli, P., 1976, Foraminiferal and ostracod biostratigraphy of the Mesozoic-Cenozoic, Scotian Shelf, Atlantic Canada: Maritime Sediments Special Publication 1, pt. b, p. 653-771.

Basse, E. de Menorval, 1959, Le domaine d'influence boreale, in Congrès des Sociétés Savantes de Paris et des Departements, Dijon, 1959, Section des Sciences, Sous-Section de Géologie, Comptes Rendus, Colloque sur le Cretace Superieur Français: Paris, Gauthier-Villars, p. 799-814.

Brown, C. W., and Pierce, R. L., 1962, Palynologic correlations in Cretaceous Eagle Ford Group, northeast Texas: American Association of Petroleum Geologists Bulletin, v. 46, no. 12, p. 2133-2147.

Brown, P. M., Brown, D. L., Reid, M. S., and Lloyd, O. B., 1979, Evaluation of the geologic and hydrologic factors related to the waste-storage potential of Mesozoic aquifers in the southern part of the Atlantic Coastal Plain, South Carolina and Georgia: U.S. Geological Survey Professional Paper 1088, 37 p.

Brown, P. M., Miller, J. A., and Swain, F. M., 1972, Structural and stratigraphic framework, and spatial distribution of permeability of the Atlantic Coastal Plain, North Carolina to New York: U.S. Geological Survey Professional Paper 796, 79 p.

Bukry, David, 1969, Upper Cretaceous coccoliths from Texas and Europe: Kansas University Paleontological Contributions [51], Protista 2, 79 p.

Christopher, R. A., 1972, Palynological evidence for assigning an Upper Cretaceous age to the Vick Formation, Bibb County, Alabama [abs]: Geological Society of America, Abstracts with Programs, v. 4, no. 2, p. 66.

1977 , Selected normapolles pollen genera and the age of the Raritan and Magothy Formations (Upper Cretaceous) of northern New Jersey, in Owens, J. P., Sohl, N. F., and Minard, J. P., eds., A field guide to Cretaceous and lower Tertiary beds of the Raritan and Salisbury Embayments, New Jersey, Delaware, and Maryland: American Association of Petroleum GeologistsSociety of Economic Paleontologists and Mineralogists, Guidebook for Annual Convention, Washington, D.C., June 12-16, 1977 , p. 58-69.

1979a, Normapolles and triporate pollen assemblages from the Raritan and Magothy Formations (Upper Cretaceous) of New Jersey: Palynology, v. 3, p. 73-121.

$1979 b$, Lower Upper Cretaceous palynostratigraphy of the eastern and western Gulf Coastal Plains [abs]: Geology of the southeastern Coastal Plain, Second Symposium, Program and Abstracts, Americus, Ga., March 5-6, 1979, p. 6.

1982, The occurrence of the Complexiopollis-Atlantopollis zone (palynomorphs) in the Eagle Ford Group (Upper Cretaceous) of Texas: Journal of Paleontology, v. 56, p. 525-541. 
Christopher, R. A., Owens, J. P., and Sohl, N. F., 1979, Late Cretaceous palynomorphs from the Cape Fear Formation of North Carolina: Southeastern Geology, v. 20, no. 3, p. 145-159.

Cobban, W. A., and Scott, G. R., 1972, Stratigraphy and ammonite fauna of the Graneros Shale and Greenhorn Limestone near Pueblo, Colorado: U.S. Geological Survey Professional Paper $645,108 \mathrm{p}$.

Doyle, J. A., 1969a, Angiosperm pollen evolution and biostratigraphy of the basal Cretaceous formations of Maryland, Delaware, and New Jersey [abs]: Geological Society of America Abstracts with Programs, [v. 1] pt. 7, p. 51.

$1969 \mathrm{~b}$, Cretaceous angiosperm pollen of the Atlantic Coastal Plain and its evolutionary significance: Arnold Arboretum Journal, v. 50, p. 1-35.

Doyle, J. A., and Robbins, E. I., 1977, Angiosperm pollen zonation of the continental Cretaceous of the Atlantic Coastal Plain and its application to deep wells in the Salisbury Embayment: Palynology, v. 1, p. 43-78.

Eicher, D. L., and Worstell, Paula, 1970, Cenomanian and Turonian Foraminifera from the Great Plains, United States: Micropaleontology, v. 16 , no. 3 , p. 269-324.

Folger, D. W., Hathaway, J. C., Christopher, R. A., Valentine, P. C., and Poag, C. W., 1978, Stratigraphic test well, Nantucket Island, Massachusetts: U.S. Geological Survey Circular 773, $28 \mathrm{p}$.

Gartner, Stefan, Jr., 1968, Coccoliths and related calcareous nannofossils from Upper Cretaceous deposits of Texas and Arkansas: Kansas University Paleontological Contributions [48], Protista $1,56 \mathrm{p}$.

Gohn, G. S., Christopher, R. A., Smith, C. C., and Owens, J. P., 1978, Preliminary stratigraphic cross sections of Atlantic Coastal Plain sediments of the Southeastern United States-Cretaceous sediments along the South Carolina coastal margin: U.S. Geological Survey Miscellaneous Field Studies Map MF-1015-A.

Gohn, G. S., Higgins, B. B., Smith, C. C., and Owens, J.P., 1977, Lithostratigraphy of the deep corehole (Clubhouse Crossroads corehole 1) near Charleston, South Carolina: U.S. Geological Survey Professional Paper1028-E, p. 59-70.

Gohn, G. S., Smith, C. C., Christopher, R. A., and Owens, J. P., 1980, Preliminary stratigraphic cross sections of Atlantic Coastal Plain sediments of the Southeastern United States-Cretaceous sediments along the Georgia coastal margin: U.S. Geological Survey Miscellaneous Field Studies Map MF-1015-C.

Groot, J. J., Penny, J. S., and Groot, C. R., 1961, Plant microfossils and age of the Raritan, Tuscaloosa, and Magothy Formations of the Eastern United States: Palaeontographica Abteilung B, v. 108, p. 121-140.

Hall, R. E., Poppe, L. J., and Ferrebee, W. M., 1980, A stratigraphic test well, Martha's Vineyard, Massachusetts: U.S. Geological Survey Bulletin 1488, 19 p.

Hancock, J. M., 1959, Les ammonites du Cénomanien de la Sarthe, in Congrès des Sociétés Savantes de Paris et des Départements, Dijon, 1959, Section des Sciences, Sous-Section de Géologie, Comptes Rendus, Colloque sur le Crétacé Supérieur Français: Paris, Gauthier-Villars, p. 249-252.

Hattner, J. G., and Wise, S. W., 1980, Upper Cretaceous nannofossil biostratigraphy of South Carolina: South Carolina Geology, v. 24 , no. 2, p. 41-117.

Hazel, J. E., Bybell, L. M., Christopher, R. A., Fredericksen, N. O., May, F. E., McLean, D. M., Poore, R. Z., Smith, C. C., Sohl, N. F., Valentine, P.C., and Witmer, R. J., 1977, Biostratigraphy of the deep corehole (Clubhouse Crossroads corehole 1) near Charleston, South Carolina: U.S. Geological Survey Professional Paper 1028-F, p. 71-89.

Jeffries, R. P. S., 1962, The paleoecology of the Actinocamax plenus subzone (lowest Turonian) in the Anglo-Paris Basin: Paleontology, v. 4 , pt. 4 , p. $609-647$.
Juignet, Pierre, 1976, Présentation du Crétacé moyen dans l'ouest de la France; Remarques sur les stratotypes du Cénomanien et du Turonien, in Reyment, R. A., and Thomel, Gérard, eds., Événements de la partie moyenne du Crétacé: Muséum d'Histoire Naturelle Nice Annales, v. 4, p. 2.1-2.12 [1979].

Juignet, Pierre, Kennedy, W. J., and Lebert, André, 1978, Le Cénomanien du Maine; formations sédimentaires et faunes d'Ammonites du stratotype: Provence Univesité, Annales, Géologie Méditerraneene, v. 5, no. 1, p. 87-99.

Kennedy, W. J., and Hancock, J. M., 1976, The mid-Cretaceous of the United Kingdom, in Reyment, R. A., and Thomel, Gérard, eds., Événements de la partie moyenne du Crétacé: Muséum d'Historie Naturelle Nice Annales, v. 4, p. 5.1-5.72 [1979].

Kennedy, W. J., and Juignet, Pierre, 1973, Observations on the lithostratigraphy and ammonite succession across the CenomanianTuronian boundary in the environs of LeMans (Sarthe, N.W. France): Newsletters on Stratigraphy, v. 2, no. 4, p. 189-202.

Lecointre, Georges, 1959, Le ,Turonian dans sa région type, la Touraine, in Congrès des Sociétés Savantes de Paris et des Départements, Dijon, 1959, Section des Sciences, Sous-Section de Géologie, Comptes Rendus, Colloque sur le Crétacé Supérieur Français: Paris, Gauthier-Villars, p. 415-423.

Leopold, E. B., and Pakiser, H. M., 1964, A preliminary report on the pollen and spores of the pre-Selma Upper Cretaceous strata of western Alabama: U.S. Geological Survey Bulletin 1160-E, p. 71-95.

Magne, Jean, and Polveche, J., 1961, Sur le niveau à Actinocamax plenus (Blainville) du Boulonnais: Société Géologique du Nord Annales, v. 81, pt. 1, p. 47-62.

Manivit, Helene, Bick, A., and others, 1979, Calcareous nannofossil events in the Lower and Middle Cretaceous: INA Newsletter (International Nannoplankton Association Proceedings), v. 1, no. 1, p. N7.

Manivit, Helene, Perch-Nielsen, Katharina, Prins, B., and Verbeek, J. W., 1977, Mid-Cretaceous calcareous nannofossil biostratigraphy: Nederlandse Akademie van Wetenschappen Proceedings, Ser. B, v. 80, p. 169-181.

Perry, W. J., Minard, J. P., Weed, E. G. A., Robbins, E. I., and Rhodehamel, E. C., 1975, Stratigraphy of Atlantic coastal margin of United States north of Cape Hatteras; brief survey: American Association of Petroleum Geologists Bulletin, v. 59, no. 9 , p. 1529-1548.

Pessagno, E. A., Jr, 1969, Upper Cretaceous stratigraphy of the western Gulf Coast area of Mexico, Texas, and Arkansas: Geological Society of America Memoir 111, $139 \mathrm{p}$.

Petters, S. W., 1976, Upper Cretaceous subsurface stratigraphy of Atlantic Coastal Plain of New Jersey: American Association of Petroleum Geologists Bulletin, v. 60, no. 1, p. 87-107.

Phillips, P. P., and Felix, C. J., 1971, A study of Lower and Middle Cretaceous spores and pollen from the Southeastern United States, II, Pollen: Pollen et Spores, v. 13, p. 439-473.

Poag, C. W., 1977, Foraminiferal biostratigraphy, in Scholle, P. A., ed., Geological studies on the COST No. B-2 well, U.S. Atlantic Outer Continental Shelf area: U.S. Geological Survey Circular 750, p. 35-36.

1980, Foraminiferal stratigraphy, paleoenvironments, and depositional cycles in the outer Baltimore Canyon Trough, in Scholle, P. A., ed., Geological studies of the COST No. B-3 well, United States mid-Atlantic Continental Slope area: U.S. Geological Survey Circular 833, p. 44-65.

Poag, C. W., and Hall, R. E., 1979, Foraminiferal biostratigraphy, paleoecology, and sediment accumulation rates, in Scholle, P. A., ed., Geological studies of the COST GE-1 well, United States South Atlantic Outer Continental Shelf area: U.S. Geological Survey Circular 800, p. 49-63.

Porthault, Bernard, Thomel, Gérard, and Villoutreys, Olivier de, 
1967, Étude biostratigraphique du Cénomanien du bassin supérieur de l'Estéron (Alpes-Maritimes); le problème de la limite Cénomanian-Turonian dans le sud-est de la France: Société Géologique de France Bulletin, Ser. 7, v. 8 (1966), no. 3, p. 423-439.

Powell, J. D., ed., 1970, Field trip guidebook: First Interamerican Micropaleontological Colloquium, Dallas, Texas, July 19-30, 36 p., with appendix of $91 \mathrm{p}$.

Rawson, P. F., Curry, Dennis, and others, 1978, A correlation of Cretaceous rocks in the British Isles: Geological Society of London Special Report 9, $70 \mathrm{p}$.

Richards, H. G., 1943, Fauna of the Raritan Formation of New Jersey: Philadelphia Academy of Natural Sciences Proceedings, v. 95, p. 15-32.

Robaszynski, Francis, 1971, Les foraminifères pélagiques des "Diéves" crétacées aux abords du golfe de Mons (Belgique): Société Géologique du Nord Annales, v. 91, no. 1, p. 31-38.

1976. Approche biostratigraphique du Cénomano-Turonien dans le Hainaut Franco-Belge et le nord de la France, in Reyment, R. A., and Thomel, Gérard, eds., Événements de la partie moyenne du Crétace: Muséum d'Histoire Naturelle Nice Annales, v. 4, p. 8.1-8.23 [1979].

Robaszynski, Francis, and Caron, Michèle, eds., 1979, Atlas de foraminiferes planctoniques du Crétacé moyen (Mér Boréale et Tethys), v. 1: Cahiers de Micropaléontologie, no. 1, 185 p.

Robbins, E. I., Perry, W. J., and Doyle, J. A., 1975, Palynological and stratigraphic investigations of four deep wells in the Salisbury Embayment of the Atlantic Coastal Plain: U.S. Geological Survey Open-File Report 75-307, $120 \mathrm{p}$.

Scholle, P. A., ed., 1979, Geological studies of the COST GE-1 well, United States South Atlantic Outer Continental Shelf area: U.S. Geological Survey Circular 800, 114 p.

Sirkin, L. A., 1974, Palynology and stratigraphy of Cretaceous strata in Long Island, New York, and Block Island, Rhode Island: U.S. Geological Survey Journal of Research, v. 2, no. 4, p. 431-440.

Smith, C. C., 1975, Upper cretaceous calcareous nannoplankton zonation and stage boundaries: Gulf Coast Association Geological Societies Transactions, v. 25, p. 263-278.

1981, Calcareous nannoplankton and stratigraphy of late Turonian, Coniacian, and early Santonian age of the Eagle Ford and Austin Groups of Texas: U.S. Geological Survey Professional Paper 1075, $98 \mathrm{p}$.

Stephenson, L. W., 1952, Larger invertebrate fossils of the Woodbine Formation (Cenomanian) of Texas: U.S. Geological Survey Professional Paper 242, 226 p.

1954, Additions to the fauna of the Raritan Formation (Cenomanian) of New Jersey: U.S. Geological Survey Professional Paper 264-B, p. 25-43.

Stover, L. E., 1966, Cretaceous coccoliths and associated nannofossils from France and the Netherlands: Micropaleontology, v. 12, p. 133-167.

Swain, F. M., and Brown, P. M., 1972, Lower Cretaceous, Jurassic(?) and Triassic Ostracoda from the Atlantic coastal region: U.S. Geological Survey Professional Paper 795, 55 p.

Thierstein, H. R., 1973, Lower Cretaceous calcareous nannoplankton
biostratigraphy:[Austria] Geologisches Bundesanstalt Abhandlungen, v. 29, $52 \mathrm{p}$.

1976, Mesozoic calcareous nannoplankton biostratigraphy of marine sediments: Marine Micropalentology, v. 1, no. 4, p. 325-362.

Valentine, P. C., 1977, Nannofossil biostratigraphy, in Scholle, P. A., ed., Geological studies on the COST No. B-2 well, U.S. mid-Atlantic Outer Continental Shelf area: U.S. Geological Survey Circular 750, p. 37-40.

1979a, Regional stratigraphy and structure of the Southeast Georgia Embayment, in Scholle, P. A., ed., Geological studies of the COST GE-1 well, United States South Atlantic Outer Continental Shelf area: U.S. Geological Survey Circular 800, p. 7-17.

$1979 \mathrm{~b}$, Calcareous nannofossil biostratigraphy and paleoenvironmental interpretation, in Scholle, P. A., ed., Geological studies of the COST GE-1 well, United States South Atlantic Outer Continental Shelf area: U.S. Geological Survey Circular 800 , p. $64-70$.

1980, Calcareous nannofossil biostratigraphy, paleoenvironments, and post-Jurassic continental margin development, in Scholle, P. A., ed., Geological Studies of the COST No. B-3 well, United States mid-Atlantic Continental Slope area: U.S. Geological Survey Circular 833, p. 67-84.

1981, Continental margin stratigraphy along U.S. Geological Survey seismic line 5-Long Island Platform and western Georges Bank Basin: U.S. Geological Survey Miscellaneous Field Studies Map MF-857, 2 sheets.

1982, Upper Cretaceous subsurface stratigraphy and structure of coastal Georgia and South Carolina: U.S. Geological Survey Professional Paper 1222, $32 \mathrm{p}$.

van Hinte, J. E., 1976, A Cretaceous time scale: American Association of Petroleum Geologists Bulletin, v. 60, no. 4, p. 498-516.

Verbeek, J. W., 1976, Upper Cretaceous calcareous nannoplankton zonation in a composite section near El Kef, Tunisia: Nederlandse Akademie van Wetenschappen Proceedings, Ser. B, v. 79 , no. 2 , p. $129-148$.

1977a, Calcareous nannoplankton biostratigraphy of Middle and Upper Cretaceous deposits in Tunisia, southern Spain, and France: Utrecht Micropaleontological Bulletins, v. 16, $157 \mathrm{p}$.

1977b, Late Cenomanian to early Turonian calcareous nannofossils from a section southeast of Javernant (Dept. Aube, France): Nederlandse Akademie van Wetenschappen Proceedings, Ser. B, v. 80, no. 1, p. 20-22.

Vries, H. E. de, 1977, Late Cenomanian to early Turonian planktonic Foraminifera from a section southeast of Javernant (Dept. Aube, France): Nederlandse Akademie van Wetenschappen Proceedings, Ser. B, v. 80, no. 1, p. 23-38.

Wolfe, J. A., and Pakiser, H. M., 1971, Stratigraphic interpretations of some Cretaceous microfossil floras of the middle Atlantic States: U.S. Geological Survey Professional Paper 750-B, p. B35-B47.

Wonders, A. A. H., and Verbeek, J. W., 1977, Correlation of planktonic foraminiferal and calcareous nannofossil zonations of late Albian, Cenomanian and Turonian: Nederlandse Akademie van Wetenschappen Proceedings, Ser. B, v. 80, no. 1, p. 7-15. 